NBER WORKING PAPER SERIES

\title{
DISAGGREGATING EMPLOYMENT PROTECTION: THE CASE OF DISABILITY DISCRIMINATION
}

\author{
Christine Jolls \\ J.J. Prescott \\ Working Paper 10740 \\ http://www.nber.org/papers/w10740 \\ NATIONAL BUREAU OF ECONOMIC RESEARCH \\ 1050 Massachusetts Avenue \\ Cambridge, MA 02138 \\ September 2004
}

Thanks to Josh Angrist, David Autor, Ian Ayres, John de Figueiredo, Thomas DeLeire, Lawrence Katz, Anup Malani, Thomas Miles, Paul Oyer, and seminar participants and discussants at the American Economics Association Annual Meeting, the Harvard Labor Economics Workshop, the Harvard Law and Economics Seminar, the Society of Labor Economists' Annual Meeting, the University of Virginia Law and Economics Seminar, the American Law and Economics Association Annual Meeting, and the NBER Summer Institute for helpful comments. We are also grateful to Jerry Ling, Jane Maschka, and Charlotte Sanders for outstanding research assistance; to David Autor and Mark Duggan for providing us with their state-level Social Security Administration data and state unemployment rate series; and to Harvard Law School librarians Deanna Barmakian, Maura Burns, and Mindy Kent for extensive help in locating historical state laws governing employment discrimination against individuals with disabilities. J.J. Prescott also acknowledges financial support from the John M. Olin Center at Harvard Law School. The views expressed herein are those of the author(s) and not necessarily those of the National Bureau of Economic Research.

(C2004 by Christine Jolls and J.J. Prescott. All rights reserved. Short sections of text, not to exceed two paragraphs, may be quoted without explicit permission provided that full credit, including $@$ notice, is given to the source. 
Disaggregating Employment Protection: The Case of Disability Discrimination

Christine Jolls and J.J. Prescott

NBER Working Paper No. 10740

September 2004

JEL No. I18, J18, J21, J23, J71, J78, K31

\begin{abstract}
Studies of the effects of employment protection frequently examine protective legislation as a whole. From a policy reform perspective, however, it is often critical to know which particular aspect of the legislation is responsible for its observed effects. The American with Disabilities Act (ADA), a 1990 federal law covering over 40 million Americans, is a clear case in point. Several empirical studies have suggested that the passage of the ADA reduced rather than increased employment opportunities for individuals with disabilities. To the extent this is true, it is crucial to credibly disentangle the different features of this complex and multi-faceted law. Separately evaluating the distinct aspects of the ADA is important not only for determining how the law might best be reformed if some aspects of it produce negative employment effects, but also for improving our understanding of the potential consequences of ADA-like provisions in race and other civil rights laws. This paper exploits state-level variation in pre-ADA legal regimes governing disability discrimination to separately estimate the employment effects of each of the ADA's two primary substantive provisions. We find strong evidence that the immediate post-enactment employment effects of the ADA are attributable to its requirement of "reasonable accommodations" for disabled employees rather than to its potential imposition of firing costs for such employees. Moreover, the pattern of the ADA's effects across states suggests, contrary to widely discussed prior findings based on national-level data, that declining disabled employment after the immediate post-ADA period reflects other factors rather than the ADA itself.
\end{abstract}

Christine Jolls

Harvard Law School

Cambridge, MA 02138

and NBER

cjolls@nber.org

J.J. Prescott

Department of Economics

MIT

50 Memorial Drive

Cambridge, MA 02142

jprescott@stanfordalumni.org 


\section{Introduction}

A large literature examines the effects of employment protection on employment levels and other labor market outcomes for protected workers. In much of this literature, "employment protection" is taken to be a simple unitary measure. Thus, for instance, in studying the effects of employment protection on European and Asian unemployment, recent papers by Nickell (1997), Blanchard and Wolfers (2000), and Besley and Burgess (2004) measure the level of protection or labor regulation using single-dimension measures from OECD or other data sources. Similarly, Oyer and Schaefer (2000) study the effects of employment protection on employment levels and other labor market outcomes in the United States by examining the overall effect of a multi-faceted antidiscrimination law, the Civil Rights Act of 1991. In many areas, the fact that effects are identified from a single change in the legal regime means that there is no separate source of variation for identifying which particular components of the new regime may be primarily responsible for the observed effects; in other cases there are simply not enough sources of variation to disaggregate the separate components of "employment protection." Such limitations on the empirical findings are unfortunate, however, because it is difficult to evaluate potential policy reforms without an understanding of the specific sources of observed labor market effects.

The growing literature on the employment effects of the Americans with Disabilities Act of 1990 (ADA) is a clear case in point. Several recent empirical studies have suggested that the ADA, a law that broadly regulates the treatment of individuals with disabilities in the workplace and elsewhere, has reduced the employment of individuals with disabilities (DeLeire 2000, 2003; Acemoglu and Angrist 2001). To the extent this is true - a closely debated question to which we will return in our empirical analysis - it is critical from a policy perspective to determine which specific features of the ADA may be primarily responsible for the negative employment effect. While DeLeire (2003:259-60) suggests that those interested in improving disabled employment opportunities "should reconsider their support of the ADA as the vehicle for achieving that goal," policy reform targeted to embracing and preserving the ADA - a law passed virtually unanimously by both houses of Congress and signed with enthusiasm by a Republican president—but improving the law's efficacy appears far more promising from a practical 
standpoint than policy reform premised on the broad conclusion that the ADA should be abandoned as a means of helping individuals with disabilities. If empirical work on protective legislation such as the ADA is to have genuine policy relevance, it is critical to determine the specific source of the observed labor market effects of the legislation.

Despite the voluminous literature on the employment effects of the ADA, the question of why the ADA might have a negative effect on disabled employment has received essentially no systematic empirical attention. If the ADA's provisions render individuals with disabilities more costly to employ but — because of the difficulty of enforcing prohibitions on discrimination in hiring (Donohue and Heckman 1991) — do not effectively prevent employers from refusing to hire these individuals in the first place, then it is unremarkable that the law could be found to reduce rather than increase disabled employment. But almost no empirical attention has been devoted to the question of just why the ADA might increase the costs of, and thereby cause the disemployment of, individuals with disabilities.

Two central provisions of the ADA seem most likely to increase the cost of employing disabled individuals. First, the ADA mandates that employers provide "reasonable accommodations" to individuals with disabilities — such as purchasing special equipment or altering workplace structures or procedures - unless such accommodations would create "undue hardship" for the employer. Such mandated accommodations impose obvious costs, though the precise magnitude of these costs may be uncertain (Blanck 1996). Second, by prohibiting discriminatory discharge on the basis of disability, the ADA creates "firing costs" associated with the employment of individuals with disabilities. These costs reflect the anticipated expenses (litigation and otherwise) of terminating disabled employees even for lawful reasons; such costs arise because the legal system must now be convinced that the termination was not discriminatory. Unlike prohibitions on discriminatory failure to hire, prohibitions on discriminatory termination are likely to give rise to a significant amount of litigation by employees (Donohue and Heckman 1991). The ADA, in potentially generating these firing costs, parallels other civil rights statutes, such as Title VII of the Civil Rights Act of 1964 and the Age Discrimination in Employment Act of 1967. The large existing literature on Title VII's effects contains competing suggestions on whether 
the law has increased (contrary to the firing costs prediction) or decreased (consistent with the firing costs prediction) employment levels of protected workers (Chay 1998; Heckman and Payner 1989; Donohue and Siegelman 1991). In light of the existing empirical uncertainty about the validity of the firing costs account, an empirical investigation of the role of firing costs under the ADA is an important next step in this literature.

Because the ADA imposed both a reasonable accommodations requirement and potential firing costs at the same time (upon its initial enactment), existing studies comparing disabled employment levels before and after the ADA — including the studies by DeLeire and by Acemoglu and Angrist—are not well-suited to separating out the effects of the ADA's reasonable accommodations requirement and its potential imposition of firing costs. ${ }^{1}$ The present study seeks to isolate and evaluate the two distinct explanations for reduced disabled employment after the ADA by exploiting the substantial state-level variation in disability discrimination regimes that existed prior to the ADA's enactment. During the preADA period, some states' disability discrimination regimes tracked the ADA in both requiring reasonable accommodations for disabled workers and subjecting employers to a "traditional antidiscrimination prohibition" (forbidding discrimination on the basis of disability in hiring, firing, and terms and conditions of employment), with its associated firing costs. During the same period, other states imposed traditional antidiscrimination prohibitions but departed from the eventual approach of the ADA in not requiring employers to make reasonable accommodations. Finally, a third group of states imposed no limits whatever on private employers' treatment of disabled workers in the pre-ADA period. By separately evaluating the effects of the ADA — with its dual imposition of a reasonable accommodations requirement and a traditional antidiscrimination prohibition with its accompanying firing costs — on

\footnotetext{
${ }^{1}$ Acemoglu and Angrist briefly attempt to examine the issue of the relative role of the two distinct types of legal requirements by testing whether "separation rates" for disabled workers fell during the post-ADA period; they find no discernible effect on separation rates and therefore tentatively suggest that negative effects of the ADA may result primarily from the law's reasonable accommodations requirement. However, as Acemoglu and Angrist emphasize, the separation rate information is "plagued by considerable measurement error," and this noise may explain their failure to find an effect of the ADA on separation rates. In contrast to Acemoglu and Angrist, Baldwin and Schumacher (2002) find that the relative rate of involuntary job changes for disabled compared to nondisabled workers fell between 1990 and 1993, although again accuracy of measurement may be affecting these results. Overall, separation rate data does not seem to be a reliable way to disaggregate the employment effects of the ADA's distinct provisions.
} 
disabled employment in each of these three distinct state groups, we are able to provide a measure of the relative importance of the ADA's reasonable accommodations requirement and its traditional antidiscrimination prohibition in driving the disabled employment effects of the ADA's enactment.

We estimate that in the years just after its enactment the ADA produced approximately a 10 percent decline in disabled employment in states in which the law's reasonable accommodations requirement was an innovation, compared to states in which a similar requirement existed at the state level prior to the ADA's enactment. By contrast, we consistently find little to no effect of the ADA's enactment on disabled employment in states in which the law's traditional antidiscrimination prohibition, with its associated firing costs, was an innovation, compared to states with similar preexisting prohibitions. Our results therefore suggest that the reasonable accommodations requirement of the ADA, rather than its imposition of firing costs, played the central role in the ADA's near-term employment effects.

The state-law variation in pre-ADA disability discrimination regimes not only allows us to disaggregate the relationship between the ADA's enactment and post-ADA employment patterns, but also provides a new source of variation for probing the robustness of the causal relationship asserted by some studies between the ADA and the employment trends observed over the 1990s (DeLeire 2000, 2003; Acemoglu and Angrist 2001). As the significant scholarly debate over the ADA's employment effects, culminating in a recent book-length treatment by Dennis Stapleton and Richard Burkhauser (2003), clearly illustrates, a perennial concern with any study of outcomes before and after the implementation of a new federal program is that concurrent unmeasured changes other than the passage of the new lawincluding shifts in the economic, social, and technological environment — may be the actual causes of the observed changes in outcomes. Our research, by separately studying the effects of the ADA in those states that had similar regimes in place prior to the ADA's enactment, in those states in which the ADA was an innovation only with respect to imposing a reasonable accommodations requirement, and in those states in which the ADA was a complete innovation, provides an important new lens on the voluminously debated question of the causal relationship between the ADA and declines in disabled employment over 
the 1990s (DeLeire 2000, 2003; Acemoglu and Angrist 2001; Stapleton, Houtenville and Goodman 2001; Bound and Waidmann 2002; Beegle and Stock 2003; Kruse and Schur 2003; Stapleton and Burkhauser 2003). Our results clearly support a causal relationship between the ADA and declines in disabled employment in the years immediately following the law's enactment, but beyond that period our findings - contrary to the existing work by DeLeire and by Acemoglu and Angrist—indicate that disabled employment declines do not appear to be causally linked to the ADA. In particular, while relative disabled employment was lower in those later years than in the period immediately before the ADA's enactment, we find no difference in the employment reduction between states in which the ADA was and was not an innovation.

The remainder of the paper is organized as follows. Section II describes the data used in our empirical analysis. Section III presents our basic approach and results. Section IV describes a variety of robustness checks. Section V offers a concluding discussion.

\section{Data}

\section{A. Pre-ADA State-Law Regimes}

Tables 1, 2, A1, and A2 report the results of our detailed legal research into state disability discrimination regimes prior to the ADA. We rely on primary sources (the actual text of statutes and judicial decisions) and, as described in the tables, have traced statutory provisions through all of their preADA amendments and code sections. We have also read all of the pre-ADA reported case law, which provides judicial interpretations of states' statutory provisions, plus unreported case law available on Westlaw. The judicial opinions turn out to be a crucial source for us because a number of states imposed reasonable accommodations requirements by judicial decision rather than by statutory provision, and because in a few states (most notably Michigan) case law holdings significantly illuminated the meaning of ambiguous or even conflicting statutory provisions that would otherwise have been read differently.

As Tables 1 and 2 reveal, states in the pre-ADA period had varying statutory and judicial regimes governing private employers' treatment of disabled workers. The largest group of states tracked the ADA 
in mandating some form of traditional antidiscrimination prohibition (forbidding discrimination on the basis of disability in hiring, firing, and terms and conditions of employment), with its associated firing costs, but differed from the ADA in not imposing a reasonable accommodations requirement; these states are listed in Table 1, and we refer to them throughout as the "protection without accommodation" states. A second group of states, listed in Table 2, imposed substantive requirements parallel to those ultimately imposed by the ADA; we refer to these states as the "ADA-like" states. Finally, a third group of states (consisting of Alabama, Arkansas, and Mississippi), which we term the "no protection" states, set no limits whatsoever on private employers' treatment of disabled workers prior to the ADA's enactment.

We address below concerns that there are only three states in this group and that all of them are from the southern United States. ${ }^{2}$ No states in the pre-ADA period imposed reasonable accommodations requirements without having traditional antidiscrimination prohibitions. ${ }^{3}$

\section{B. Disability Status and Other Individual Data}

For the disability status of individuals - as well as for other variables such as employment levels and various demographic and other controls - we draw on the March Current Population Survey (CPS). Throughout, we refer to data by its year of observation (the year preceding the March survey), and we restrict attention to individuals aged 21 through 58. Variables and summary statistics for the years 1988 to 1998 are reported in Table 3.

\footnotetext{
${ }^{2}$ All three of the "no protection" states did appear to prohibit disability discrimination by public employers (akin to the employment provisions of the federal Rehabilitation Act of 1973), but they did not prohibit such discrimination by private employers. Naturally, given our interest in this paper in examining the effects of the ADA, we focus on the pre-ADA state-law regimes governing private employers.

${ }^{3}$ Although this research is the first to employ a comprehensive dataset based on original legal sources for state-level disability discrimination regimes, other studies have made some use of data on these state-level regimes. Acemoglu and Angrist (2001) briefly use state-law information as an instrument in their empirical analysis and, in so doing, restrict attention to a limited number of pre-ADA state-law regimes that provided for "misdemeanor charges or civil penalties" in the event of an employer violation. We do not characterize state regimes along the dimension of whether or not such sanctions were available because the ordinary set of sanctions - money damages along with nonmonetary relief such as reinstatement - did not vary significantly across the 47 states with pre-ADA disability discrimination regimes. Beegle and Stock (2003) also use state-law information in their empirical analysis and, instead of examining the ADA's effect across states, examine the effects of the state-law enactments themselves; we discuss their approach and results at some length in section III below.
} 
The CPS variable for disability requires some discussion. ${ }^{4}$ The CPS definition of disability comes from the March income supplement and reflects the subject's answer to the question, "Does [respondent] have a health problem or a disability which prevents him/her from working or which limits the kind or amount of work he/she can do?" Under the ADA, meanwhile, an individual is disabled if he or she has a physical or mental impairment that substantially limits a major life activity, has a record of such an impairment, or is regarded as having such an impairment. An affirmative answer to the CPS question certainly does not map perfectly or even that closely onto the ADA's definition of disability (Schwochau and Blanck 2000:299-300).

The reasons that the CPS and ADA definitions may diverge are several. First, individuals who answer the CPS question affirmatively may be incorrectly reporting health conditions or impairments that limit work - perhaps because they are unable to find work — and may not in fact be truly impaired (see Kreider and Pepper 2002). Second, only certain types of genuine impairments that may limit work have been deemed by the Supreme Court to be covered by the ADA (Sutton v. United Airlines, 527 U.S. 471 (1999)). Third, alongside these respects in which the CPS measure may be broader than the ADA measure, the CPS measure may be narrower in not including those with a record of impairment or who are regarded as impaired, but who are not actually impaired. ${ }^{5}$

While the CPS measure would clearly provide a poor basis for some empirical conclusions — such as the absolute number of people protected by the ADA at a given point of time - the estimates we report are not vulnerable on this ground because our approach uses the CPS measure to assess changes in employment levels after the ADA's enactment. Burkhauser, Daly, Houtenville, and Nargis (2002) provide evidence from National Health Interview Survey (NHIS) data that employment changes over time for populations defined by work limitations (as under the CPS) are not significantly different from

\footnotetext{
${ }^{4}$ Burkhauser and Daly (2002:219-20) describe varying approaches to the definition of disability. As Acemoglu and Angrist (2001) note, while the CPS disability question seems to refer to the individual's status at the time of the March survey, the question actually serves as a lead-in question for a series of questions about disability income in the preceding year.

${ }^{5}$ The Equal Employment Opportunity Commission (EEOC) claims data (available at http://www.eeoc.gov/stats/ada.html) suggest that about 15 percent of EEOC claims under the ADA involve the "record" and "regarded as" prongs of the ADA's disability definition.
} 
employment changes over time for populations defined by impairments (closer to the ADA's approach). Thus, we think that the CPS disability question has enough overlap with the definition of disability under the ADA that studying how those who answer "yes" to the survey question were affected by the ADA in terms of their employment levels allows one to learn something important about the effects of the law on disabled employment. ${ }^{6}$

The most important potential concern with the use of the CPS measure of disability or, indeed, the use of any survey-based measure of disability for purposes of examining pre- and post-ADA employment levels of individuals with disabilities is that the ADA's enactment could itself have altered the composition of the group responding "yes" to the disability survey question. Kruse and Schur (2003) describe several routes by which the passage of the ADA could alter the nature of the group of individuals answering "yes" to a disability survey question such as the one in the CPS. If such changes occurred, then apparent disemployment effects of the ADA could actually be effects of the law on the nature of the population being counted as disabled. In section IV below, we closely examine the time trend in affirmative answers to the CPS disability question, and, consistent with prior work on the prospect of such composition bias (Acemoglu and Angrist 2001:935; Beegle and Stock 2003:855-56), we do not find evidence that compositional changes are driving our findings. ${ }^{7}$

\section{Empirical Approach and Results}

The ADA was enacted in July of 1990, so throughout the empirical analysis we compare employment levels in two-year periods starting in 1990 to employment levels in the two-year period immediately preceding 1990. Because the ADA did not go into effect until two years after its enactment, it is possible that effects lagged behind the 1990 enactment date; alternatively, the time immediately

\footnotetext{
${ }^{6}$ In the future, the CPS is likely to include disability-related questions that map more closely onto the ADA's definition (see Kruse and Hale 2003:6-9). No matter how precise this information, however, it will obviously not be available for either the time period in which the ADA was passed or for the years prior to the ADA's enactment. In this light, use of the CPS measure from the pre-ADA and immediate post-ADA periods is a reasonable step in seeking to measure the effects of the ADA on disabled employment.

${ }^{7}$ The CPS was redesigned between the 1993 and 1994 surveys, corresponding to observation years 1992 and 1993. Acemoglu and Angrist $(2001: 925,951)$ offer analysis suggesting that the redesign does not materially affect an understanding of the ADA's employment effects.
} 
following enactment might have witnessed the largest employment effects as employers in the "protection without accommodation" and "no protection" states—while facing new potential costs of employing disabled workers down the road—were not yet restricted by ADA (or ADA-like) provisions and thus could, for instance, discharge or refuse to hire someone because of the person's need for reasonable accommodations without incurring any sort of legal risk during this period. Extensive enactment-period media coverage of the ADA suggests that many managerial employees in fact learned of the ADA right at the point of its enactment. ${ }^{8}$ With respect to our "pre-ADA" period of 1988-1989, because the ADA actually received widespread media coverage as early as the latter half of 1989 — when the law was already widely anticipated — our use of 1988-1989 as the period against which to measure the law's effects will, if anything, tend to bias our estimates against finding an effect of the ADA, as employers' behavior conceivably could have been affected as early as the second half of $1989 .{ }^{9}$

\section{A. Univariate Results}

Mean employment levels across our three state groups provide a first view of the basic effect of the ADA's reasonable accommodations requirement and its traditional antidiscrimination prohibition, with its associated firing costs, on disabled employment after the ADA's enactment. Table 4 reports the mean employment levels in weeks per year for disabled and nondisabled workers, before (1988-1989) and after (all subsequent pairs of years) the passage of the ADA, separately for each of our three state groups: the "protection without accommodation" group, containing states with traditional antidiscrimination

\footnotetext{
${ }^{8}$ A search of the Lexis-Nexis News Group File for mentions of the ADA in 1990 yielded 965 hits.

${ }^{9}$ During the latter half of 1989 , media sources frequently referred to the certain or virtually certain passage of the ADA the following year. In the legal literature, for instance, Chatoff (1989) stated that the ADA "inevitably will" become law, while Gardner (1989) wrote that Congress "seems almost certain to enact" the ADA "in the very foreseeable future." In the popular media, Shapiro (1989) stated of the ADA that "President Bush . . guaranteed the bill's passage with his support," while Calkins (1989) quoted a disability advocate's confident declaration that "for the first time ever, people with disabilities will have civil rights protection under federal law equal to the protection already afforded to members of minority groups and to women." Of particular interest are industry periodicals targeted to employers and their managerial employees; in this category, Romeo (1989) reports in an article in Nation's Restaurant News that at a meeting of the National Restaurant Association the "Americans with Disabilities Act was mentioned several times"; that a member of the Association's Human Resources Committee stated that the law "will affect us in the very near future"; and that another Association official stated that the "ADA seems certain to pass." Similarly, an editorial entitled "Accommodating Disabled Workers in the Construction Industry," published in October of 1989 in the Engineering News-Record, stated that passage of the ADA "seems certain to follow."
} 
prohibitions but no reasonable accommodations requirements prior to the ADA's enactment; the "ADAlike" group, with states that had both traditional antidiscrimination prohibitions and reasonable accommodations requirement prior to the ADA's enactment; and the "no protection" group, containing states that imposed no restrictions on private employers' treatment of disabled workers prior to the ADA's enactment. We use two-year windows before and after the change in the legal setting (similar to Katz 1998 and Autor, Donohue, and Schwab 2002).

Table 4's top panel compares disabled versus nondisabled employment levels before and after the ADA in "protection without accommodation" states with disabled versus nondisabled employment levels before and after the ADA in "ADA-like" states. Because the absence or presence of a pre-ADA reasonable accommodations requirement is the dimension along which the two state groups differ, this first comparison provides a measure of the effect of the ADA's imposition of a reasonable accommodations requirement. As Table 4 shows, in "protection without accommodation" states, where the ADA's reasonable accommodations requirement was an innovation, disabled employment declined by 1.35 weeks per year in 1990-1991 compared to 1988-1989, while nondisabled employment showed a far smaller decline of 0.23 weeks per year; by contrast, in "ADA-like" states, in which the substantive requirements of the pre-ADA state-level regimes tracked those of the ADA, disabled employment actually increased by 0.83 weeks per year in 1990-1991 compared to 1988-1989, while nondisabled employment was virtually unchanged (a decline of 0.03 weeks per year).

Taking the difference between the two within-state-group differences for 1990-1991 compared to 1988-1989, the mean-based difference-in-difference-in-difference (DDD) estimate for the change in disabled employment generated by the imposition of a reasonable accommodations requirement is -1.98 weeks per year (column 3 of Table 4). Given the base number of weeks employed for disabled workers prior to the ADA's enactment—16.25 in the "protection without accommodation" states and 18.22 in the "ADA-like" states - the drop of 1.98 weeks represents over a 10 percent decline in disabled employment. The evidence of declining relative disabled employment in "protection without accommodation" states compared to "ADA-like" states continues in 1991-1992 and 1992-1993, and then disappears in 1993- 
1994 and subsequent pairs of years - the first suggestion of a near-term but not long-term effect of the ADA. We discuss this timing pattern in further detail below. Notice the reassuring fact that in all of the near-term post-ADA comparisons, nondisabled employment—in contrast to disabled employment — is relatively stable between the pre- and post- ADA periods in both the "protection without accommodation" and the "ADA-like" states.

The bottom panel of Table 4 compares "no protection" states, with no pre-ADA legal restrictions on private employers' treatment of disabled workers, to "protection without accommodation" states, with only traditional antidiscrimination prohibitions prior to the ADA's enactment. This comparison thus provides a measure of the effect of imposing a traditional antidiscrimination prohibition (an innovation in the "no protection" states but not in the "protection without accommodation" states). Our mean-based DDD estimate for the implementation of such a prohibition bounces between negative and positive over the 1990-1991 through 1997-1998 "after" periods and is always small in magnitude and statistically indistinguishable from zero. The mean-based results in Table 4 provide a first suggestion that the ADA's reasonable accommodations requirement, rather than its potential imposition of firing costs, is the main source of a near-term negative effect of the law on disabled employment.

\section{B. Regression Framework}

Our regression analysis employs a straightforward DDD specification like that used, for example, in Gruber (1994) and Collins (2003). All regressions take the form:

$$
\begin{aligned}
Y_{i j t}=\quad \beta_{0} & +\beta_{l} X_{i j t}+\beta_{2} A D A_{t}+\beta_{3} D I S_{i}+\beta_{4} L P_{j}+\beta_{5} N P_{j}+\beta_{6}\left(A D A_{t} * D I S_{i}\right) \\
& +\beta_{7}\left(A D A_{t} * L P_{j}\right)+\beta_{8}\left(A D A_{t} * N P_{j}\right)+\beta_{9}\left(D I S_{i} * L P_{j}\right)+\beta_{10}\left(D I S_{i} * N P_{j}\right) \\
& +\beta_{I I}\left(A D A_{t} * D I S_{i} * L P_{j}\right)+\beta_{I 2}\left(A D A_{t} * D I S_{i} * N P_{j}\right),
\end{aligned}
$$

where $Y$ is weeks worked; $i$ indexes individuals, $j$ indexes states, and $t$ indexes years; $X$ is a vector of demographic and state-level economic characteristics; $A D A$ is a dummy variable equal to 1 in the postADA period; DIS is a dummy variable equal to 1 for disabled individuals; $L P$ is a dummy variable equal to 1 for states offering limited protection in the form of a traditional antidiscrimination prohibition prior 
to the ADA's enactment (the "protection without accommodation" state group); and NP is a dummy variable equal to 1 for states in the "no protection" state group. The $L P$ and NP dummy variables measure effects relative to those in the "ADA-like" group. ${ }^{10}$

The coefficients of interest in equation (1) are the coefficients on the triple interaction terms, $A D A_{t} * D I S_{i} * L P_{j}$ and $A D A_{t} * D I S_{i} * N P_{j}$. The coefficient $\beta_{11}$ on the first of these terms measures the change between the pre- and post-ADA periods in disabled versus nondisabled outcomes in "protection without accommodation" states (those with traditional antidiscrimination prohibitions but no reasonable accommodations requirements prior to the ADA) relative to this same change in "ADA-like" states (those with both reasonable accommodations requirements and traditional antidiscrimination prohibitions prior to the ADA). In other words, $\beta_{11}$ tells us how relative disabled outcomes changed in states in which the ADA's reasonable accommodations requirement, but not its traditional antidiscrimination prohibition, was new (the "protection without accommodation" group) compared to how these outcomes changed in states in which neither substantive requirement of the ADA was new (the "ADA-like" group).

Our approach here does not assume that the enactment of the ADA made no difference at all in states that had substantively comparable pre-ADA protections (the "ADA-like" states); among other things the enactment of the federal statute made available Equal Employment Opportunity Commission (EEOC) enforcement and altered other procedural aspects of pre-existing disability discrimination law, such as the availability of federal court adjudication (see generally Neuborne 1977), and these changes may have influenced disabled outcomes. Effects of the federal regime that are identical across states are permissible within a DDD framework, although such effects cannot be identified.

\footnotetext{
${ }^{10}$ Instead of looking at such relative effects, one could examine separate effects within each of the three state groups. In that model the coefficients of interest would be $A D A_{t} * D I S_{i} * L P_{j}, A D A_{t} * D I S_{i} * N P_{j}$, and $A D A_{t} * D I S_{i}$ * $A D_{j}$, where $A D$ is a dummy variable equal to 1 for states in the "ADA-like" group. Table A3 reports results from specifications that omit $A D A_{t} * D I S_{t}$ and instead estimate the coefficient on $A D A_{t} * D I S_{i} * A D_{j}$. In these specifications, the coefficients on $A D A_{t} * D I S_{i} * L P_{j}$ and $A D A_{t} * D I S_{i} * N P_{j}$ measure overall effects rather than effects relative to the "ADA-like" states. Returning to the original specification reflected in equation (1), because there are three (nonoverlapping) groups of states in our study, several of the interactions between the dummy variables are always zero (in particular, $L P_{j} * N P_{j}, A D A_{t} * L P_{j} * N P_{j}, D I S_{i} * L P_{j} * N P_{j}$, and $A D A_{t} * D I S_{i} * L P_{j} * N P_{j}$ ), and thus these drop out of equation (1).
} 
Of course, if the ADA had differential effects across the "protection without accommodation" and "ADA-like" groups for reasons unrelated to the substantive legal provisions in effect in these groups, then our estimate of $\beta_{11}$ would pick up those additional effects along with the effect of imposing a reasonable accommodations requirement. If, for example, states in the "ADA-like" group tended to be systematically more vigorous in accepting and enforcing civil rights claims brought by disabled individuals than states in the "protection without accommodation" group, then $\beta_{11}$ would measure not only the effect of imposing a reasonable accommodations requirement but also the effect of supplementing moderate or limited enforcement of disability discrimination law in the "protection without accommodation" states with the more robust procedures provided by the ADA. Any attempt to control directly for cross-state variation in pre-ADA enforcement behavior using the number of discrimination charges brought under the various state laws would be confounded by the significant endogeneity of charge rates and the employment level (our dependent variable). Acemoglu and Angrist (2001) address this endogeneity issue in their use of discrimination charge data by instrumenting for state charge rates with a variable for whether the state had a particular type of pre-ADA disability discrimination law (one providing for "misdemeanor charges or civil penalties"), but that approach is not open to us here given the role the state-law information already plays in our analysis.

Nonetheless, we think it is quite unlikely that our estimate of $\beta_{l 1}$ will be picking up enforcement differences that could confound the effect on disabled employment of imposing a reasonable accommodations requirement. The timing of the state-law enactments suggests that the "ADA-like" states are not the systematically more aggressive, pro-disabled-worker states; in most cases the states that had reasonable accommodations requirements prior to the ADA's enactment were those that instituted disability discrimination regimes relatively late in the game, while the "protection without accommodation" states were those "early to the party" in protecting civil rights of disabled workers (see date columns in Tables 1 and 2). Thus, if anything, our estimate of $\beta_{l 1}$ will tend to understate the potential disemployment effect for disabled workers of imposing a reasonable accommodations 
requirement, given the most plausible direction of any pre-ADA enforcement differences between the two state groups.

While $\beta_{11}$ measures the effect of imposing a reasonable accommodations requirement, equation (1) also provides us with a direct measure of the effect of simultaneously imposing both a reasonable accommodations requirement and a traditional antidiscrimination prohibition. The coefficient $\beta_{12}$ measures the change between the pre- and post-ADA periods in disabled versus nondisabled outcomes in “no protection" states (those with no pre-ADA restrictions on employers' treatment of disabled workers) relative to this same change in "ADA-like" states, and the difference in legal regimes between those two groups is the absence (in the former) versus the presence (in the latter) of a reasonable accommodations requirement and a traditional antidiscrimination prohibition prior to the ADA. Thus the difference in the two groups' outcomes $\left(\beta_{12}\right)$ is a measure of the effect of imposing both of these provisions with the enactment of the $\mathrm{ADA}$; it then follows that the difference $\beta_{12}-\beta_{11}$, which is also reported in our tables, measures the effect of imposing just a traditional antidiscrimination prohibition.

All of the regressions reported below contain controls for individual $i$ 's age, race, sex, educational attainment, marital status, union membership, and receipt of disability benefits, and for the state unemployment rate (except where precluded by fixed effects, as noted below) and the interaction of disability with the state unemployment rate. By the nature of the DDD methodology, our approach controls for national time trends in employment, the general effect of disability on employment, stategroup specific employment effects, and interactions of each of these factors with the others. Many of our regressions also include state, year, and state*year fixed effects, although in those specifications we are unable to identify the effects of the state unemployment rate and of the $A D A_{t}, L P_{j}$, and $N P_{j}$ variables from above and their interactions with each other. Importantly, because all of our regressions include the interaction of disability with the state unemployment rate, our approach controls for the possibility that individuals with disabilities may face especially poor employment prospects when unemployment rates are high - an important control given the early 1990s recession immediately following the ADA's enactment (Kruse and Schur 2003). 


\section{Regression Results}

The top panel of Table 5 reports the results of the basic specification in equation (1). Consistent with the findings in Table 4 , the estimate for $\beta_{11}$, the effect of imposing a reasonable accommodations requirement, is clearly negative for the post-ADA year pairs 1990-1991, 1991-1992, and 1992-1993, with estimates ranging from -1.54 to -2.51 weeks per year. Thus, as before, imposing a reasonable accommodations requirement seems to produce in the neighborhood of a 10 percent decline in disabled employment in the near-term aftermath of the ADA's enactment. Meanwhile, again parallel to the results in Table 4 , the estimate for $\beta_{12}-\beta_{11}$, the effect of imposing a traditional antidiscrimination prohibition, over the post-ADA years 1990-1991, 1991-1992, and 1992-1993 is small in magnitude, inconsistent in sign, and never statistically significant. Thus, our results once again suggest that the reasonable accommodations requirement of the ADA, rather than its traditional antidiscrimination prohibition, was the source of a short-term negative effect of the law on disabled employment. The second panel in Table 5 shows that our results are unchanged when state, year, and state*year fixed effects are included, and the top panel of Table A4 verifies that the results are unchanged when state, state*year, and state*disability fixed effects (to control for compositional changes) are included.

Our basic finding of a significant negative employment effect of imposing a reasonable accommodations requirement contrasts with the conclusions of a recent paper by Beegle and Stock (2003), whose results also point in a direction opposite that of DeLeire $(2000,2003)$ and Acemoglu and Angrist (2001). Beegle and Stock use Census data for 1970, 1980, and 1990 to study the effects of the enactment of state laws governing disability discrimination in the pre-ADA period (whereas we examine the effects of the ADA across different groups of states characterized by their varying pre-ADA legal regimes). Beegle and Stock find no significant effect of the enactment of reasonable accommodations requirements (in contrast with our finding) and no significant effect of the enactment of disability discrimination law in general (in contrast with the findings of DeLeire and of Acemoglu and Angrist). 
The difference between Beegle and Stock's results and those of others (including us) is attributable, we think, to a combination of the relatively imprecise information on state laws used by Beegle and Stock and some features of their econometric approach. ${ }^{11}$ Regarding information on state laws, as detailed above, we obtained information exclusively from primary sources and traced laws through all of their pre-ADA amendments and code provisions. By contrast, Beegle and Stock rely on secondary sources, which in some cases prove to be inaccurate and in any event do not allow them to identify the year of a law's enactment (just the year when the law is first referred to in the secondary source in question). The imprecision in the information about state laws will affect Beegle and Stock's empirical analysis when the dating errors cross decade markers, as they do in a number of cases. ${ }^{12}$ This noise in the coding of the state-law explanatory variable will tend to bias estimates toward zero (see Autor, Donohue, and Schwab 2002:28), and this may help to explain the difference between Beegle and Stock's findings and the results obtained by us, DeLeire, and Acemoglu and Angrist.

\footnotetext{
${ }^{11}$ An additional difference between Beegle and Stock's analysis and ours is that most of their regressions include year and disability*year fixed effects; incorporating disability*year fixed effects proves to have a dramatic effect on their results. In our analysis, by contrast, the bottom panel of Table A4 shows that adding year and disability*year fixed effects to our basic specification has little effect on our results.

${ }^{12}$ For instance, Beegle and Stock, relying on a secondary source, state that Arkansas had a law, §20-14-303, prohibiting private sector disability discrimination by 1987 . However, this statute did not, in 1987, cover employment discrimination, although it did cover private sector discrimination in other areas, such as access to restaurants and other public places. (The full text of the statute is available in the AR-STANN87 historical legislative database on Westlaw.) In alphabetical order, other states that are incorrectly classified by Beegle and Stock in terms of the decade in which private sector employment discrimination laws relating to disability were enacted include Colorado, Louisiana, Massachusetts, Missouri, North Carolina, Oregon, and Rhode Island. Of this group, Colorado and Louisiana are misclassified as to both the decade in which a traditional antidiscrimination prohibition was enacted and the decade in which a reasonable accommodations requirement was enacted; Missouri, North Carolina, and Rhode Island are misclassified as to the decade in which a traditional antidiscrimination prohibition was enacted; and Massachusetts and Oregon are incorrectly classified as to the decade in which a reasonable accommodations requirement was enacted. See Tables 1 and 2 below for state law enactment information.

Hotchkiss (2002) also makes some use of the pre-ADA state disability discrimination regimes, and differs from Beegle and Stock in relying on primary legislative materials rather than secondary sources. However, she nonetheless incorrectly categorizes a substantial number of states, in many instances probably because a state statute prior in time to the one she located also regulated disability discrimination in employment; these errors may contribute to her finding of a limited effect of the ADA's enactment across state groups. States miscategorized by Hotchkiss, in terms of date of enactment, include Alaska, California, Colorado, Hawaii, Illinois, Massachusetts, New Jersey, North Carolina, South Carolina, South Dakota, Texas, and Virginia. (In the case of Alaska, California, and South Dakota, Hotchkiss explicitly notes that "exact original coverage [is] not available.") Some of the dating errors will not affect Hotchkiss's empirical results; she examines the effects of state laws enacted between 1981 and 1991, and, thus, a dating error outside this period will not affect her results. However, in the case of six statesAlaska, Hawaii, Massachusetts, North Carolina, South Carolina, and Texas - the dating error affects the classification of states over the 1981-1991 period.
} 
Apart from the imprecision in Beegle and Stock's characterization of state-law regimes, their empirical methodology may be less well-suited than ours to pinning down accurately the employment effects of reasonable accommodations requirements and traditional antidiscrimination prohibitions imposed by disability discrimination law. Beegle and Stock employ a framework in which some states have promulgated a particular law during a given time period while others have not, and in which changes in outcomes across the two groups of states are then compared. In that setting, a risk always exists that adjustments in the relative labor market outcomes in the different states reflect not the policy shifts under study but rather some set of underlying state-level social or economic changes that simultaneously caused, or at least occurred contemporaneously with, the changes in the state laws (see Besley and Case 2000). As Beegle and Stock note, "[i]f laws were disproportionately passed in states where the disabled were [already] faring better, we would expect the laws to have smaller effects and our empirical results to underestimate the negative impact of the legislation (relative to random assignment of the laws, including states where the negative impact of the laws would be larger)." Examining the enactment of the ADA against a background of a well-established diversity of state law, by contrast, reduces the concern about this sort of omitted-variables bias because there is less reason to fear that the degree to which the ADA was an innovation in a given state is correlated with state-specific social or economic changes, given that virtually all of the state laws in question were enacted well before the ADA (see Tables 1 and 2).

Returning to our empirical results, the 93-94 through 97-98 columns of Table 5 show that in this period neither imposing a reasonable accommodations requirement nor imposing a traditional antidiscrimination prohibition had a statistically significant effect on disabled employment; estimates for $\beta_{11}$ range from -0.60 to 0.70 , while those for $\beta_{12}-\beta_{11}$ range from -0.25 to 0.87 . In other words, beginning in 1993-1994 and going forward the ADA's enactment had statistically indistinguishable effects across the three state groups. What is especially striking about these later "post-ADA" years is that it is precisely in 1993-1994 that the estimated coefficient on the term $A D A_{t}{ }^{*} D I S_{i}$, measuring the common effect of the ADA across states, becomes negative and statistically significant; therefore, from 1993-1994 forward, movements in relative disabled employment were downward and similar in 
magnitude across all three state-law regimes - a sharp contrast with the clear differential pattern, based on pre-ADA state legal regimes, in the early years after the ADA's enactment. The bottom panel of Table 5 underlines the point by showing that in a specification that simply ignores state-law information entirely (by setting $N P_{j}=L P_{j}=0$ in equation (1)), the estimated coefficients on $A D A_{t}{ }^{*} D I S_{i}$ in 1993-1994 and forward are quite similar to the estimated coefficients on these variables in the top and middle panels, in which the separate effects of being in the "protection without accommodation" and "no protection" state groups are not restricted to zero.

Thus, our results for 1993-1994 and forward, while consistent with existing findings of a persistent decline in disabled employment over the 1990s relative to the pre-ADA period, reveal the absence of any link between the degree of employment effects in this later period and the degree to which the ADA was actually a legal innovation relative to pre-ADA state law. Our findings appear to deny earlier studies attributing declining disabled employment in 1993-1994 and forward to the ADA's enactment the obvious theoretical explanations for their conclusions, as we find no evidence that either the imposition of a reasonable accommodations requirement or the firing costs potentially associated with a traditional antidiscrimination prohibition can explain the decline in disabled employment in 1993-1994 and forward.

The juxtaposition of a clear state-group pattern, in a predictable direction, in the immediate postADA period (through 1992-1993) and no state-group differences in the later years raises some questions about the longevity of any negative employment effects of the ADA. It seems plausible in light of our findings that the apparent negative effect of the ADA on disabled employment in 1993-1994 and subsequent years reflects not the impact of the ADA itself but, rather, other contemporaneous changes disproportionately affecting individuals with disabilities. Otherwise, it is not immediately clear why the magnitude of the disabled disemployment effect after the ADA (in 1993-1994 and forward) would have no relationship to the degree to which the ADA was a legal innovation in a given state, when such a relationship clearly existed in the immediate post-enactment period. Just below we discuss reasons that 
the ADA's imposition of a reasonable accommodations requirement might have had only a short-term negative effect on disabled employment.

\section{Discussion}

Our results indicate that in the near-term after the ADA's enactment, the law's reasonable accommodations requirement, but not its traditional antidiscrimination prohibition with its potential firing costs, had a significant negative effect on disabled employment. The significant negative effect of the reasonable accommodations requirement on disabled employment in the period just after the ADA's enactment may reflect the fact that many accommodations, including physical alterations to the workplace and modification of workplace policies, impose obvious but often one-time costs on employers - costs that may well have been exaggerated or particularly salient in employers' minds just after the ADA's enactment. ${ }^{13}$ Employers might naturally have responded to such perceived costs by curtailing their hiring of disabled workers, particularly in the period between the ADA's enactment and effective dates because in that period curtailed hiring on account of accommodation costs would not have been illegal in the states in which the ADA's reasonable accommodations requirement was an innovation. Further reasons that the effect of the ADA's reasonable accommodations requirement on disabled employment could have been more negative in the short term than in the medium and long term include the ADA's important symbolic effect and the resulting changes in attitudes over time; the possibility that reasonable accommodations could ultimately increase the flow of qualified disabled applicants following a shortterm reduction as disabled individuals responded to the ADA by pursuing more education (see Jolls 2000); and declining accommodation costs in response to technological changes and judicial refinements of the ADA's requirements. The conclusion that the true employment effects of the ADA are short-term

\footnotetext{
${ }^{13}$ While some observers have pointed to evidence that accommodation costs may often be modest (Blanck 1996), measurement issues and skewed samples of accommodations suggest that relatively limited weight should be attached to such evidence (Stein 2000:1677). In any event it is quite clear that some legally mandated accommodations - for instance, the need to hire readers for blind employees, as specified by federal regulations (see 29 CFR $§ 1630.2(0)$ ) - are in fact extremely costly for employers.
} 
rather than permanent effects is consistent with Kirchner (1986), who emphasizes that the consequences of laws such as the ADA may differ significantly over different time horizons. ${ }^{14}$

\section{Further Robustness Checks}

This section further probes the robustness of our basic finding in Tables 4 and 5 that in the years just after the ADA's enactment, the imposition of the law's reasonable accommodations requirement, but not its traditional antidiscrimination prohibition, produced a significant decline in disabled employment. We also examine the possible role of composition effects and preexisting state-group specific employment trends in our analysis.

\section{A. Robustness to the Timing of State-Law Enactment}

The upper left-hand panel of Table 6 shows the results (for post-ADA years 1990-1991, 19911992, and 1992-1993) of estimating the basic fixed-effects specification from the middle panel of Table 5 on a subsample of observations from states in which the state-level pre-ADA disability discrimination regime was already in place prior to 1980 . We perform this check on the theory that these early enactors—which, as noted earlier, are predominantly "protection without accommodation" states—may have differed systematically in their degrees of "civil rights orientation," and thus in their enforcement environments, from the later enactors. The fact that in two of the three regressions the estimate of $\beta_{11}$ becomes even more negative than in Table 5 provides some support for our suggestion above that the estimates based on the full 50-state sample may actually understate the effect of imposing a reasonable accommodations requirement. However, some degree of caution is warranted in interpreting these results because only three states in the "ADA-like" group (Colorado, Oregon and Washington) had their preADA regimes in place prior to 1980. Subject to the caveat just noted, the robustness of our estimate of

\footnotetext{
${ }^{14}$ With respect to the short-term employment effects of the ADA's reasonable accommodations requirement, a more positive account than the one given in the text is that negative employment effects were themselves reasonable accommodations to the scheduling needs of disabled workers (see Tolin and Patwell 2003). Given that we observe declines in weeks worked, not hours worked per week, however, and that the decline is limited to the immediate post-ADA period, it seems difficult to view the negative employment effects as the fact, rather than the potential consequence, of mandated accommodation.
} 
$\beta_{11}$ in a sample of states with more uniform enactment dates also responds to the possible concern that, if there are either lags or bursts in state law effectiveness shortly after a state law is put on the books, then our 50-state results could be confounded by the different average enactment dates across the "protection without accommodation" and "ADA-like" state groups. Our estimate of $\beta_{12}-\beta_{11}$, the effect of imposing a traditional antidiscrimination prohibition, is also quite stable across the broader (all states) and narrower (pre-1980 enactors only) samples.

\section{B. Robustness to Variation in Employer-Size Coverage Thresholds}

As shown in Tables 1 and 2, pre-ADA state legal regimes varied significantly in the numerical employer-size thresholds they established for coverage by the state legal regime. To mitigate any concern with bias from these significantly varying thresholds, we re-estimated the basic fixed-effects specification from the middle panel of Table 5 using only observations from states with employer-size coverage thresholds of 15 employees (the ultimate ADA threshold) or higher. (Only one state, Delaware, had a threshold of greater than 15 employees.) Our results, reported in the upper right-hand panel of Table 6, again point to a negative effect of imposing a reasonable accommodations requirement and essentially no effect of imposing a traditional antidiscrimination prohibition. The fact that controlling for variation in employer-size coverage thresholds does not affect our basic finding provides some further support for our earlier suggestion that "protection without accommodation" and "ADA-like" states are not differentially affected by the ADA's enactment because of a difference in the general civil-rights orientation of these two state groups, as such a difference in general civil-rights orientation would probably tend to correlate at least to some degree with a more versus less aggressive approach to the coverage of small employers.

\section{Robustness to Alternative Measures of Disability Benefits}

At around the time the ADA was enacted, the generosity of federal disability benefits was increasing substantially (Bound and Waidmann 2002). Higher disability benefit levels provide an independent ground for reduced disabled employment because higher benefit levels reduce disabled 
individuals' need or desire for wage-based income. The increase in the number of disabled individuals receiving disability benefits, as well as the decrease in weeks worked for individuals with disabilities, over the 1990s are readily apparent from the summary statistics reported in Table 3.

While all of the regressions reported thus far contain controls for disability benefits, the shift in federal disability benefit levels is actually of less concern for our study than for prior studies that compare overall disabled employment outcomes before and after the ADA's enactment (DeLeire 2000, 2003; Acemoglu and Angrist 2001) because our DDD framework examines disabled employment levels in one group of states relative to disabled employment levels in other state groups, and thus changes in federal benefits levels are not as likely to matter for our results. Still, changes in federal disability benefits could affect our analysis if for some reason the resulting changes in disabled individuals' need or desire for wage income (and thus their work incentives) differed systematically across our three state groups. Autor and Duggan (2003), for instance, note that work incentives depend on the relationship between disability benefit levels and wages, and thus states experiencing smaller wage increases (or larger wage declines) would tend to have more individuals receiving federal disability benefits, and thus not seeking and obtaining employment, at any given federal level of these benefits. If wage levels across states were for some reason correlated with pre-ADA state-law disability discrimination regimes, then the effects of changes in federal disability benefits generosity (mediated through the Autor-Duggan mechanism) might be captured by, and therefore bias, our results.

The regressions reported thus far control for disability benefits receipt using a dummy variable for whether individuals received federal disability benefits through either the Disability Insurance (DI) program or the Supplemental Security Income (SSI) program. ${ }^{15}$ Because, however, the measure of disability benefits receipt in the March CPS is not ideal, we perform additional robustness checks using state-level DI and SSI applications and receipts in the population from Social Security Administration records. The lower panel of Table 6 reports the results of re-estimating the basic fixed-effects

\footnotetext{
${ }^{15}$ The CPS provides information on receipt of benefits from the Old-Age, Survivors, and Disability Insurance (OASDI) and SSI programs. However, because our sample does not include individuals 59 and older, OASDI benefits should be exclusively from the DI program.
} 
specification from the middle panel of Table 5 using, respectively, the percent of the state population receiving disability benefits interacted with the disability status dummy variable (left-hand panel) and the percent of the state population applying for disability benefits interacted with the disability status dummy variable (right-hand panel). (Including state fixed effects means we cannot separately identify main effects of the new disability benefits variables.) Our results for the effects of imposing a reasonable accommodations requirement versus a traditional antidiscrimination prohibition are, once again, quite consistent with our benchmark estimates from Table 5.

\section{Robustness to Variation in Economic Environment}

As noted above, our basic specification controls for variation in states' economic environments by including state unemployment rate and the interaction of disability and state unemployment rate. However, as a further check on the possibility that unobservable economic variation across states might be influencing our results, we re-estimated the basic fixed-effects specification from the middle panel of Table 5 without state unemployment rate information; if removing these controls does not affect our results, then it seems unlikely that further unobservable economic differences are playing an important role. The results, shown in the upper panel of Table A5, are quite similar to those in the benchmark specification reported in Table 5 .

\section{E. Geographic Robustness}

We noted earlier that, while both the "protection without accommodation" and "ADA-like" groups are large and well-balanced across the country, the "no protection" group consists of only three states, all of which are from the southern United States (Alabama, Arkansas, and Mississippi). Our estimate of the effect of the ADA's reasonable accommodations requirement will not be affected by the limited geographic diversity of the "no protection" group because that effect is identified solely from the comparison of employment changes in the "protection without accommodation" group with similar changes in the "ADA-like" group; but our estimate of the effect of the ADA's traditional 
antidiscrimination prohibition, based on a comparison of "no protection" and "protection without accommodation" states, could be distorted by this aspect of the pre-ADA state legal landscape. In particular, if some unobserved shock occurred in the southern region of the country between the pre- and post-ADA periods, and that shock differentially affected disabled and nondisabled workers, then our estimate of $\beta_{12}-\beta_{11}$ could capture the effect of this unobserved shock in addition to any effect caused by the enactment of the ADA.

A straightforward strategy to alleviate the concern about a possible "southern trend" is simply to re-estimate equation (1) on just the southern states from each of our three state groups. The "protection without accommodation" group in this regression includes Georgia, Kentucky, South Carolina, and Tennessee, while the "ADA-like" group contains Louisiana and North Carolina. (The "no protection" group is, as before, Alabama, Arkansas, and Mississippi.) Although, not surprisingly, the precision of our estimates falls with the sharp reduction in sample size, the lower panel of Table A5 shows that the results of estimating the basic fixed-effects specification from the middle panel of Table 5 on the nine-state southern sample follow the same basic pattern as the results from the full 50-state sample.

\section{F. Composition of the Disabled Group}

As noted earlier, an important question that arises with the use of a survey-based disability measure, such as the CPS measure used in our analysis, is the possibility of law-driven changes in the composition of the group answering the survey question affirmatively. If the group of individuals identifying themselves as disabled in response to the CPS survey question changed in shape or size as a result of the ADA's enactment, then measured changes in disabled employment levels between the preand post-ADA periods may capture differences in the nature of the group answering "yes" to the survey question rather than employer-side effects of the new legal regime. Kruse and Schur (2003:49), for instance, find evidence from Survey of Income and Program Participation data of higher numbers of individuals reporting severe limitations in 1993 than in 1991, and it would not be surprising for those with severe limitations to have lower chances of employment. 
An important advantage of the framework we employ is that changes over time in the shape or size of the group of individuals identifying themselves as disabled in response to the CPS question will not affect our analysis unless these changes vary with the pre-ADA legal regime of the state in which an individual lives. While nationwide changes certainly seem plausible, state-varying changes are less likely. This is not to say that they are inconceivable, however; one obvious possibility is that legal reform may make disability more socially accepted and thus lead more people to identify themselves as disabled. If this were the case, then changes in disability identification with the ADA could be more substantial in states in which the ADA was a more significant innovation.

For state-group specific changes in individuals' identification as disabled to confound our results, one of three things would have to be the case. First, significant innovation through the ADA in the "protection without accommodation" and "no protection" states could for some reason have made individuals with worse employment prospects than those who identified as disabled prior to the ADA more likely to identify themselves as disabled. This could produce an apparent disemployment effect for disabled workers in the states in which the ADA was a significant innovation. However, if anything one would think it would be those closest to the line between disability and nondisability, and thus those with relatively good employment prospects, who might switch from identifying as nondisabled to identifying as disabled in a state in which the ADA was a significant innovation (say because the innovation made disability more socially acceptable). Put another way, it seems rather difficult to tell a story in which those who are severely limited switch from answering the CPS question "no" to answering it "yes" when the ADA constitutes a significant innovation in their state, while those who are less severely limited do not exhibit a similar change. ${ }^{16}$

The second possibility for a confounding effect on our results is that individuals with reasonably good employment prospects became less likely in the wake of significant legal innovation through the ADA in "protection without accommodation" or "no protection" states to identify themselves as disabled,

\footnotetext{
${ }^{16}$ Even if it is the case (as suggested by Kruse and Schur 2003:49) that the proportion of disabled individuals who report severe disabilities has increased on a nationwide basis in the post-ADA years, it is unclear how this effect could plausibly be correlated with the degree to which the ADA was a significant legal innovation in a given state.
} 
precisely because the reform helped them to obtain and retain jobs (see Kirchner 1986:83). Again, this could produce an apparent disemployment effect for disabled workers in states in which the ADA was a significant innovation. If the legal reform did lead to a decline in the reporting of disability, then the proportion of disabled individuals should either shrink or grow more slowly in "protection without accommodation" and "no protection" states than in "ADA-like" states. Figure 1 graphs the proportion of disabled individuals over time across our three state groups from 1988 to 1998, while Figure 2 presents corresponding fourth-order polynomial trend lines. Over this period it does not appear that disability rates declined in states in which the ADA was a significant innovation (states in the "protection without accommodation" and "no protection" groups) relative to the "ADA-like" states. With respect to the "no protection" states, measuring changes between 1988 and the post-ADA years 1990-1993, Figure 1 shows that the proportion of individuals answering the CPS disability question affirmatively increased more in the "no protection" states than in the "ADA-like" states for year pairings 1988-1991 and 1988-1993, while this proportion increased more in the "ADA-like" states than the "no protection" states for year pairings 1988-1990 and 1988-1992. With respect to the "protection without accommodation" states, meanwhile, Figure 1 reveals that over 1990 and 1991 (relative to 1988) the proportion of individuals answering the CPS disability question affirmatively increased more in the "ADA-like" states (implying slower growth in the "protection without accommodation" states); but precisely the same trend was apparent in 1989, even before the ADA was enacted. In 1992 and 1993 (the other years in which we find a negative effect of the ADA on disabled employment in "protection without accommodation" states relative to "ADA-like" states), by contrast, Figure 1 shows that disability rates are virtually identical across the two state groups, as they also were in the 1988 start year.

A final possibility with respect to the composition of the disabled group, suggested by the work of Autor and Duggan (2003), is that states in which the ADA was a significant legal innovation also for some reason happened to be states that were experiencing smaller wage increases or larger wage declines around the time of the ADA's enactment; as described above, individuals in such states would both tend to be more likely to identify as disabled (to get federal disability benefits) and tend to be more likely not 
to be employed (again to be eligible for federal disability benefits). This effect could produce a spurious correlation between the ADA's enactment and employment effects across states if for some reason statelevel wage changes were correlated with pre-ADA state disability discrimination regimes. The regression results reported above (Tables 5 and 6), however, show that our results are robust to a range of controls for disability benefits receipts and applications. In sum, although we cannot entirely rule out an effect on our results of changes in the composition of the group responding affirmatively to the CPS disability question, our basic finding of a negative near-term effect of the ADA's reasonable accommodations requirement on disabled employment does not appear to be driven by such changes.

\section{G. Preexisting State-Group Specific Trends in Disabled Employment}

Our conclusion that declining disabled employment in "protection without accommodation" states relative to "ADA-like" states in the near-term post-ADA period reflects the ADA's imposition of a reasonable accommodations requirement obviously rests on the premise that the observed pattern of effects did not predate the ADA “experiment." Figure 3 graphs disabled employment trends in the "protection without accommodation" and "ADA-like" states from 1987, the first observation year in which the general disability status question was asked in the CPS, to 1992, the last year in which disabled employment in the two state groups moved in significantly different ways. (As the results reported above suggest, convergence between the two state groups began in 1993. As the earlier results from Table 4 also show, nondisabled employment was relatively stable in both state groups over the relevant period, so Figure 3 focuses on disabled employment.) These data paint a reassuring picture in which disabled employment moved roughly in tandem across the two state groups prior to 1990 and then diverged markedly in 1990-1992 (see Figure 3). A longer pre-ADA window would obviously be preferable, but the available data point to a genuine break in trend upon the ADA's enactment. 


\section{Conclusion}

This paper uses pre-ADA state-law variation to disaggregate the disabled employment effects of the two central provisions of the ADA, its reasonable accommodations requirement and its traditional antidiscrimination prohibition with associated firing costs. Our effort to disaggregate the ADA's effects in this way reflects a desire to evaluate policy reforms more tailored and more politically realistic than the broadscale recommendation that the ADA be abandoned (see DeLeire 2003). However, our empirical approach ultimately yielded a more profound challenge to the existing literature suggesting ongoing negative employment effects of the ADA. Our results suggest that while the ADA's reasonable accommodations requirement had a significant negative effect on disabled employment in the near-term after the ADA's enactment, the law may well have had no causal link to the declines in disabled employment through much of the 1990s. 


\section{References}

"Accommodating Disabled Workers in the Construction Industry." 1989. Engineering News-Record, 223(9):72.

Acemoglu, Daron and Joshua D. Angrist. 2001. "Consequences of Employment Protection? The Case of the Americans with Disabilities Act," Journal of Political Economy, 109:915-957.

Autor, David H. and Mark G. Duggan. 2003. "The Rise in Disability Rolls and the Decline in Unemployment," Quarterly Journal of Economics, 108:157-205.

-----, John J. Donohue III, and Stewart J. Schwab. 2002. "The Costs of Wrongful Discharge Laws," M.I.T. Department of Economics Working Paper No. 02-41.

Baldwin, Marjorie L. and Edward J. Schumacher. 2002. "A Note on Job Mobility Among Workers with Disabilities," Industrial Relations, 41:430-441.

Beegle, Kathryn and Wendy Stock. 2003. "The Labor Market Effects of Disability Discrimination Laws," Journal of Human Resources, 38(4):806-859.

Besley, Timothy and Robin Burgess. 2004. "Can Labor Regulation Hinder Economic Performance? Evidence from India," Quarterly Journal of Economics, 119:91-134.

---- and Anne Case. 2000. "Unnatural Experiments? Estimating the Incidence of Endogenous Policies," Economic Journal, 110:F672-F694.

Blanchard, Olivier and Justin Wolfers. 2000. "The Role of Shocks and Institutions in the Rise of European Unemployment: The Aggregate Evidence," Economic Journal, 110:C1-C33.

Blanck, Peter David. 1996. Communicating the Americans with Disabilities Act, Transcending Compliance: 1996 Follow-up Report on Sears, Roebuck and Co. Washington, DC: Annenberg Washington Program.

Bound, John and Timothy Waidmann. 2002. “Accounting for Recent Declines in Employment Rates Among the Working-Aged Disabled," Journal of Human Resources, 37(2):231-250.

Burkhauser, Richard V., Mary C. Daly, Andrew J. Houtenville and Nigar Nargis. 2002. "Self-Reported Work-Limitation Data: What They Can and Cannot Tell Us," Demography, 39(3):541-555.

-----. and Mary C. Daly. 2002. "U.S. Disability Policy in a Changing Environment," Journal of Economic Perspectives, 16:213-24.

Calkins, Phil. 1989. “A Legal Revolution,” Worklife (Mar. 22), 21.

Chatoff, Michael A. 1989. "Judge Me By What I Can Do," The National Law Journal (Oct. 2), 13.

Chay, Kenneth. 1998. "The Impact of Federal Civil Rights Policy on Black Economic Progress: Evidence from the Equal Employment Opportunity Act of 1972," Industrial and Labor Relations Review, 51:608-32.

Collins, William J. 2003. "The Labor Market Impact of State-Level Antidiscrimination Laws, 19401960," Industrial and Labor Relations Review, 56:244-272.

DeLeire, Thomas. 2000. "The Wage and Employment Effects of the Americans with Disabilities Act," Journal of Human Resources, 35:693-715.

----. 2003. "The Americans with Disabilities Act and the Employment of People with Disabilities," in The Decline in Employment of People with Disabilities (David C. Stapleton and Richard V. Burkhauser, eds.).

Donohue, John J., III, and James J. Heckman. 1991. "The Law and Economics of Racial Discrimination in Employment: Re-Evaluating Federal Civil Rights Policy," Georgetown Law Journal, 79:1713-1735. 
----- and Peter Siegelman. 1991. "The Changing Nature of Employment Discrimination Litigation," Stanford Law Review, 43:983-1033.

Gardner, John E. 1989. "Federal Labor Law Preemption of State Wrongful Discharge Claims," University of Cincinnati Law Review, 58:491-558.

Gruber, Jonathan. 1994. "The Incidence of Mandated Maternity Benefits," American Economic Review, 84:622-641.

Heckman, James J. and Brook Payner. 1989. "Determining the Impact of Federal Antidiscrimination Policy on the Economic Status of Blacks: A Study of South Carolina," American Economic Review, 79:138-177.

Hotchkiss, Julie L. 2002. "A Closer Look at the Employment Impact of the Americans with Disabilities Act" (mimeo).

Jolls, Christine. 2000. “Accommodation Mandates," Stanford Law Review, 53:223-306.

Katz, Lawrence F. 1998. "Wage Subsidies for the Disadvantaged," in Richard B. Freeman and Peter Gottschalk, eds., Generating Jobs: How to Increase Demand for Less-Skilled Workers. New York, NY: Russell Sage.

Kirchner, Corinne. 1986. "Looking Under the Street Lamp: Inappropriate Uses of Measures Just Because They Are There," Journal of Disability Policy Studies, 7:78-90.

Kreider, Brent and John V. Pepper. 2002. "Disability and Employment: Reevaluating the Evidence in Light of Reporting Errors," Center for Retirement Research Working Paper No. 2002-06.

Kruse, Douglas and Thomas Hale. 2003. "Disability and Employment: Symposium Introduction," Industrial Relations, 42:1-10.

----- and Lisa Schur. 2003. "Employment of People with Disabilities Following the ADA," Industrial Relations, 42:31-66.

Neuborne, Burt. 1977. "The Myth of Parity," Harvard Law Review, 90:1105-1131.

Nickell, Stephen. 1997. "Unemployment and Labor Market Rigidities: Europe versus North America," Journal of Economic Perspectives, 11:55-74.

Oyer, Paul and Scott Schaefer. 2000. " "Litigation Costs and Returns to Experience," American Economic Review, 92:683-705.

Romeo, Peter. 1989. "New NRA Programs Tackle Host of Industry Issues," Nation's Restaurant News, 23(40):4.

Schwochau, Susan and Peter David Blanck. 2000. "The Economics of the Americans with Disabilities Act, Part III: Does the ADA Disable the Disabled?" Berkeley Journal of Employment and Labor Law, 21:271-313.

Shapiro, Joseph P. 1989. "Liberation Day for the Disabled," U.S. News and World Report, 107(11):20.

Stapleton, David, Andrew Houtenville and Nanette Goodman. 2001. "Have Changes in Job Requirements Reduced the Number of Workers with Disabilities?" (mimeo).

----- and Richard V. Burkhauser. The Decline in Employment of People with Disabilities. Kalamazoo: W.E. Upjohn Institute for Employment Research, 2003.

Stein, Michael Ashley. 2000. "Empirical Implications of Title I," Iowa Law Review, 86:1672-1690.

Tolin, Tom and Martin Patwell. 2003. "A Critique of Economic Analysis of the ADA,” Disability Studies Quarterly, 23:130-142. 


\section{Table 1: Pre-ADA State Laws Prohibiting Disability Discrimination - "Protection Without Accommodation" States}

In the states listed in this table, pre-ADA statutory or judicial law imposed traditional antidiscrimination prohibitions but no reasonable accommodations requirements on private employers:

\begin{tabular}{|c|c|c|c|c|}
\hline & Statutory Section(s) & $\begin{array}{c}\text { Traditional } \\
\text { Antidiscrimination } \\
\text { Prohibition - } \\
\text { Date Adopted }\end{array}$ & $\begin{array}{c}\text { Reasonable } \\
\text { Accommodations } \\
\text { Requirement - } \\
\text { Date Adopted }\end{array}$ & $\begin{array}{l}\text { Employer- } \\
\text { Size } \\
\text { Threshold for } \\
\text { Coverage }^{\mathrm{a}}\end{array}$ \\
\hline Alaska & $18.80 .220(a)(1)^{*}$ & $1969^{\dagger}$ & $\mathrm{n} / \mathrm{a}$ & 1 \\
\hline California & Govt. 12940(a), 12994* & $1973^{\dagger}$ & $\mathrm{n} / \mathrm{a}^{\ddagger}$ & 5 \\
\hline Connecticut & $46 a-60(a)(1)^{*}$ & $1973^{\dagger}$ & $\mathrm{n} / \mathrm{a}$ & 3 \\
\hline Florida & $760.10(1)^{*}$ & 1977 & $\mathrm{n} / \mathrm{a}$ & 15 \\
\hline Georgia & $34-6 A-4(a)$ & 1981 & $\mathrm{n} / \mathrm{a}$ & 15 \\
\hline Hawaii & $378-2(1)$ & $1975^{\dagger}$ & $\mathrm{n} / \mathrm{a}$ & 1 \\
\hline Illinois & $68: 1-103(\mathrm{Q}), 2-102(\mathrm{~A})^{*}$ & 1971 & $\mathrm{n} / \mathrm{a}$ & 15 \\
\hline Indiana & $22-9-1-3(1)$ & 1975 & $\mathrm{n} / \mathrm{a}$ & 6 \\
\hline Kansas & $44-1009(a)(1)$ & 1974 & $\mathrm{n} / \mathrm{a}$ & 4 \\
\hline Kentucky & $207.150(1)$ & 1976 & $\mathrm{n} / \mathrm{a}$ & 8 \\
\hline Maine & $5: 4572(1)(\mathrm{A})$ & 1973 & $\mathrm{n} / \mathrm{a}$ & 1 \\
\hline Maryland & 49B:16(a)* & 1974 & $\mathrm{n} / \mathrm{a}$ & 15 \\
\hline Michigan & $37.1102(2), 1202(1)$ & $1976^{\dagger}$ & $\mathrm{n} / \mathrm{a}^{*}$ & 4 \\
\hline Missouri & $213.055 .1(1)^{*}$ & 1978 & $\mathrm{n} / \mathrm{a}$ & 6 \\
\hline Montana & $49-2-303(a), 49-4-101^{*}$ & $1974^{\dagger}$ & $\mathrm{n} / \mathrm{a}$ & 1 \\
\hline Nebraska & $48-1104$ & 1973 & $\mathrm{n} / \mathrm{a}$ & 15 \\
\hline Nevada & $613.330(1)$ & $1971^{\dagger}$ & $\mathrm{n} / \mathrm{a}$ & 15 \\
\hline New Hampshire & 354-A:8(I) & 1975 & $\mathrm{n} / \mathrm{a}$ & 6 \\
\hline New Jersey & $10: 5-4.1,-12(\mathrm{a}),-29.1$ & $1972^{\dagger}$ & $\mathrm{n} / \mathrm{a}$ & 1 \\
\hline New York & Exec. 296(1)(a) & 1974 & $\mathrm{n} / \mathrm{a}$ & 4 \\
\hline North Dakota & 14-02.4-03 & 1983 & $\mathrm{n} / \mathrm{a}$ & 10 \\
\hline Ohio & 4112.02(A) & 1976 & $\mathrm{n} / \mathrm{a}$ & 4 \\
\hline Oklahoma & 25:1302(A) & 1981 & $\mathrm{n} / \mathrm{a}$ & 15 \\
\hline South Carolina & $43-33-530$ & 1983 & $\mathrm{n} / \mathrm{a}$ & 1 \\
\hline South Dakota & $20-13-10,23.7,23.8$ & 1986 & $\mathrm{n} / \mathrm{a}^{*}$ & 1 \\
\hline Tennessee & $8-50-103(a)$ & $1976^{\dagger}$ & $\mathrm{n} / \mathrm{a}$ & $\mathrm{n} / \mathrm{a}^{\mathrm{b}}$ \\
\hline Texas & Civ. Art. $5221 \mathrm{k}: 5.01^{*}$ & $1975^{\dagger}$ & $\mathrm{n} / \mathrm{a}^{*}$ & 15 \\
\hline Utah & 34-35-6(1)(a)(i) & 1979 & $\mathrm{n} / \mathrm{a}$ & 15 \\
\hline West Virginia & $5-11-9(a)(1)^{*}$ & 1981 & $\mathrm{n} / \mathrm{a}$ & 12 \\
\hline
\end{tabular}

* Original statutory section differed from statutory section in effect immediately prior to the ADA: See Table A1 for details.

$\dagger$ Substantive amendment(s) subsequent to adoption: See Table A1 for details.

* Potential ambiguity over the existence of a reasonable accommodations requirement: See Table A2 for legal description and effect on our results of alternative characterizations.

a Number of employees, as of 1989. The column lists the number of individuals a firm had to employ before it was subject to coverage by the state's disability discrimination law.

b Neither statutory nor judicial law provided an employer-size threshold for coverage. 


\section{Table 2: Pre-ADA State Laws Prohibiting Disability Discrimination - "ADA-Like" States}

In the states listed in this table, pre-ADA statutory or judicial law imposed both traditional antidiscrimination prohibitions and reasonable accommodations requirements on private employers:

\begin{tabular}{lcccc}
\hline \hline & Statutory Section(s) & $\begin{array}{c}\text { Traditional } \\
\text { Antidiscrimination } \\
\text { Prohibition }- \\
\text { Date Adopted }\end{array}$ & $\begin{array}{c}\text { Accommodations } \\
\text { Requirement }- \\
\text { Date Adopted }\end{array}$ & $\begin{array}{c}\text { Employer- } \\
\text { Size } \\
\text { Threshold for } \\
\text { Coverage }^{\mathrm{a}}\end{array}$ \\
\hline Arizona & $41-1463(\mathrm{~B})$ & 1985 & 1985 & 15 \\
Colorado & $24-34-402(1)(\mathrm{a})^{*}$ & 1977 & $1977^{\mathrm{b}}$ & 1 \\
Delaware & $19: 723(\mathrm{~b}), 724(\mathrm{a}), 724(\mathrm{e})(2)$ & 1988 & 1988 & 20 \\
Idaho & $67-5909(1)$ & 1988 & 1988 & 10 \\
Iowa & $601 \mathrm{~A} \cdot 6(1)(\mathrm{a})^{*}$ & 1972 & $1987^{\ddagger, \mathrm{c}}$ & 4 \\
Louisiana & $46: 2254(\mathrm{~A}),(\mathrm{C})$ & 1980 & 1980 & 15 \\
Massachusetts & $151 \mathrm{~B}: 4(16)^{*}$ & $1972^{\dagger}$ & 1983 & 6 \\
Minnesota & $363.03: 1(2),(6)$ & 1973 & $1983^{\dagger, \mathrm{d}}$ & 1 \\
New Mexico & $28-1-7(\mathrm{~A}),(\mathrm{J})^{*}$ & $1973^{\dagger}$ & 1983 & 4 \\
North Carolina & $168 \mathrm{~A}-4,5(\mathrm{a})^{*}$ & $1973^{\dagger}$ & 1985 & 6 \\
Oregon & $659.425(1)$ & $1973^{\dagger}$ & 1979 & 4 \\
Pennsylvania & $43: 955(\mathrm{a}),(\mathrm{b})$ & 1974 & $1985^{\mathrm{c}}$ & 4 \\
Rhode Island & $28-5-7(1)^{*}$ & $1973^{\dagger}$ & 1986 & 1 \\
Vermont & $21: 495(\mathrm{a})(1), 495 \mathrm{~d}(6)^{*}$ & 1973 & 1981 & $\mathrm{n} / \mathrm{a}^{\mathrm{e}}$ \\
Virginia & $51.5-41(\mathrm{~A}),(\mathrm{C})^{*}$ & 1975 & 1985 & 8 \\
Washington & 49.60 .180 & 1973 & $1978^{\mathrm{c}}$ & 1 \\
Wisconsin & $111.321,322(1), 34(1)(\mathrm{b})^{*}$ & $1965^{\dagger}$ & $1981^{*}$ & 2 \\
Wyoming & $27-9-105(\mathrm{a}),(\mathrm{d})$ & 1985 & 1985 & \\
\hline
\end{tabular}

* Original statutory section differed from statutory section in effect immediately prior to the ADA: See Table A1 for details.

$\dagger$ Substantive amendment(s) subsequent to adoption: See Table A1 for details.

* Potential ambiguity over the timing of adoption of a reasonable accommodations requirement: See Table A2 for details.

a Number of employees, as of 1989. The column lists the number of individuals a firm had to employ before it was subject to coverage by the state's disability discrimination law.

b Statutory language is somewhat ambiguous but is clarified by an administrative regulation, 3 CCR 708-1, Rule 60.2(C).

c Judicial interpretation: Iowa - Cerro Gordo County Care Facility v. Iowa Civil Rights Comm'n, 401 N.W.2d 192 (Iowa 1987); Pennsylvania-Jenks v. Avco Corp., 940 A.2d 912 (Pa. Super. 1985); Washington—Holland v. Boeing Co., 583 P.2d 621 (Wash. 1978). In the case of Washington, the 1978 decision briefly mentions the existence of an administrative regulation requiring reasonable accommodations, but this regulation plays only a minor role in the court's opinion.

d Applicable only to employers with 50 or more employees.

e Neither statutory nor judicial law provided an employer-size threshold for coverage. 
Table 3: Descriptive Statistics

\begin{tabular}{|c|c|c|c|c|c|c|c|c|c|c|c|}
\hline Nondis abled & 1988 & 1989 & 1990 & 1991 & 1992 & 1993 & 1994 & 1995 & 1996 & 1997 & 1998 \\
\hline Age & 36.9 & 37.1 & 37.2 & 37.3 & 37.5 & 37.6 & 37.8 & 38.1 & 38.2 & 38.5 & 38.6 \\
\hline White & $87.8 \%$ & $87.1 \%$ & $87.0 \%$ & $86.7 \%$ & $86.1 \%$ & $85.5 \%$ & $84.3 \%$ & $86.4 \%$ & $86.3 \%$ & $86.2 \%$ & $86.3 \%$ \\
\hline Post-High School & $44.5 \%$ & $45.5 \%$ & $45.8 \%$ & $50.0 \%$ & $51.8 \%$ & $53.6 \%$ & $54.3 \%$ & $54.0 \%$ & $54.4 \%$ & $55.0 \%$ & $55.6 \%$ \\
\hline Working & $87.5 \%$ & $87.4 \%$ & $87.2 \%$ & $87.1 \%$ & $86.8 \%$ & $87.0 \%$ & $87.3 \%$ & $87.6 \%$ & $88.0 \%$ & $88.3 \%$ & $88.4 \%$ \\
\hline Weeks Worked & 40.8 & 40.8 & 40.6 & 40.4 & 40.3 & 40.5 & 40.9 & 41.3 & 41.6 & 42.0 & 42.2 \\
\hline Weekly Wage & $\$ 397$ & $\$ 422$ & $\$ 433$ & $\$ 447$ & $\$ 462$ & $\$ 481$ & $\$ 508$ & $\$ 561$ & $\$ 572$ & $\$ 595$ & $\$ 625$ \\
\hline SSI/DI & $1.32 \%$ & $1.39 \%$ & $1.38 \%$ & $1.31 \%$ & $1.54 \%$ & $1.61 \%$ & $1.66 \%$ & $1.59 \%$ & $1.60 \%$ & $1.43 \%$ & $1.27 \%$ \\
\hline Obs. & 67,907 & 74,616 & 74,980 & 74,192 & 73,525 & 70,999 & 70,686 & 61,300 & 62,088 & 62,338 & 63,137 \\
\hline Dis abled & 1988 & 1989 & 1990 & 1991 & 1992 & 1993 & 1994 & 1995 & 1996 & 1997 & 1998 \\
\hline Age & 42.5 & 42.5 & 42.2 & 42.2 & 42.1 & 42.6 & 43.0 & 43.2 & 43.2 & 43.8 & 44.0 \\
\hline White & $83.7 \%$ & $83.5 \%$ & $82.6 \%$ & $83.5 \%$ & $83.6 \%$ & $81.0 \%$ & $79.5 \%$ & $80.8 \%$ & $80.9 \%$ & $82.0 \%$ & $80.6 \%$ \\
\hline Post-High School & $23.3 \%$ & $23.6 \%$ & $25.7 \%$ & $28.5 \%$ & $30.8 \%$ & $31.3 \%$ & $32.1 \%$ & $32.9 \%$ & $34.0 \%$ & $34.9 \%$ & $35.6 \%$ \\
\hline Working & $45.0 \%$ & $45.8 \%$ & $43.4 \%$ & $43.2 \%$ & $42.7 \%$ & $40.8 \%$ & $40.8 \%$ & $39.7 \%$ & $40.2 \%$ & $37.4 \%$ & $36.6 \%$ \\
\hline Weeks Worked & 16.4 & 17.2 & 15.9 & 15.9 & 15.8 & 15.1 & 14.7 & 14.8 & 15.0 & 14.0 & 13.8 \\
\hline We ekly Wage & $\$ 307$ & $\$ 308$ & $\$ 314$ & $\$ 335$ & $\$ 317$ & $\$ 347$ & $\$ 376$ & $\$ 435$ & $\$ 396$ & $\$ 366$ & $\$ 469$ \\
\hline SSI/DI & $32.98 \%$ & $31.67 \%$ & $34.33 \%$ & $35.29 \%$ & $37.66 \%$ & $38.55 \%$ & $38.10 \%$ & $40.24 \%$ & $42.41 \%$ & $45.07 \%$ & $44.68 \%$ \\
\hline Obs. & 4,396 & 4,884 & 5,025 & 5,100 & 5,311 & 5,307 & 5,336 & 4,680 & 4,775 & 4,655 & 4,579 \\
\hline
\end{tabular}

Notes: Descriptive statistics are unweighted. Data are for individuals aged 21-58 and are reported by observation year (the year preceding the survey).

"SSI/DI" reflects the percentage of individuals who received federal disability benefits through either the Disability Insurance (DI) program or the

Supplemental Security Income (SSI) program. 
Table 4: Means Analysis by State, Time, and Disability Status

\begin{tabular}{|c|c|c|c|c|c|c|c|c|c|}
\hline \multicolumn{10}{|c|}{ "Protection Without Accommodation" States versus "ADA-Like" States } \\
\hline & 88-89 & 90-91 & 91-92 & $92-93$ & 93-94 & $94-95$ & $95-96$ & 96-97 & $97-98$ \\
\hline \multicolumn{10}{|c|}{ Protection Without Accommodation States } \\
\hline Disabled workers & $\begin{array}{r}16.25 \\
(0.29)\end{array}$ & $\begin{array}{r}14.90 \\
(0.27)\end{array}$ & $\begin{array}{r}14.67 \\
(0.26)\end{array}$ & $\begin{array}{r}14.34 \\
(0.26)\end{array}$ & $\begin{array}{r}14.43 \\
(0.26)\end{array}$ & $\begin{array}{r}14.47 \\
(0.27)\end{array}$ & $\begin{array}{r}14.33 \\
(0.28)\end{array}$ & $\begin{array}{r}14.00 \\
(0.27)\end{array}$ & $\begin{array}{r}13.48 \\
(0.27)\end{array}$ \\
\hline Time Diff. & & $\begin{array}{r}-1.35 \\
(0.39)\end{array}$ & $\begin{array}{r}-1.57 \\
(0.39)\end{array}$ & $\begin{array}{r}-1.91 \\
(0.39)\end{array}$ & $\begin{array}{r}-1.82 \\
(0.39)\end{array}$ & $\begin{array}{r}-1.78 \\
(0.39)\end{array}$ & $\begin{array}{r}-1.92 \\
(0.40)\end{array}$ & $\begin{array}{r}-2.25 \\
(0.40)\end{array}$ & $\begin{array}{r}-2.77 \\
(0.40)\end{array}$ \\
\hline Nondisabled workers & $\begin{array}{l}40.68 \\
(0.06)\end{array}$ & $\begin{array}{r}40.45 \\
(0.06)\end{array}$ & $\begin{array}{c}40.23 \\
(0.06)\end{array}$ & $\begin{array}{l}40.19 \\
(0.06)\end{array}$ & $\begin{array}{c}40.48 \\
(0.07)\end{array}$ & $\begin{array}{l}40.94 \\
(0.07)\end{array}$ & $\begin{array}{l}41.26 \\
(0.07)\end{array}$ & $\begin{array}{l}41.64 \\
(0.07)\end{array}$ & $\begin{array}{r}42.02 \\
(0.07)\end{array}$ \\
\hline Time Diff. & & $\begin{array}{r}-0.23 \\
(0.09)\end{array}$ & $\begin{array}{r}-0.46 \\
(0.09)\end{array}$ & $\begin{array}{r}-0.49 \\
(0.09)\end{array}$ & $\begin{array}{r}-0.20 \\
(0.09)\end{array}$ & $\begin{array}{r}0.25 \\
(0.09)\end{array}$ & $\begin{array}{r}0.58 \\
(0.09)\end{array}$ & $\begin{array}{r}0.96 \\
(0.09)\end{array}$ & $\begin{array}{r}1.34 \\
(0.09)\end{array}$ \\
\hline Group-Time Diff. & & $\begin{array}{r}-1.12 \\
(0.40)\end{array}$ & $\begin{array}{r}-1.12 \\
(0.40)\end{array}$ & $\begin{array}{r}-1.42 \\
(0.40)\end{array}$ & $\begin{array}{r}-1.62 \\
(0.40)\end{array}$ & $\begin{array}{r}-2.03 \\
(0.41)\end{array}$ & $\begin{array}{r}-2.50 \\
(0.41)\end{array}$ & $\begin{array}{r}-3.21 \\
(0.41)\end{array}$ & $\begin{array}{r}-4.10 \\
(0.41)\end{array}$ \\
\hline \multicolumn{10}{|l|}{ ADA-Like States } \\
\hline Disabled workers & $\begin{array}{r}18.22 \\
(0.43)\end{array}$ & $\begin{array}{r}19.05 \\
(0.42)\end{array}$ & $\begin{array}{r}19.26 \\
(0.42)\end{array}$ & $\begin{array}{r}17.79 \\
(0.42)\end{array}$ & $\begin{array}{c}16.51 \\
(0.40)\end{array}$ & $\begin{array}{r}15.79 \\
(0.40)\end{array}$ & $\begin{array}{r}15.97 \\
(0.42)\end{array}$ & $\begin{array}{c}15.98 \\
(0.43)\end{array}$ & $\begin{array}{r}14.65 \\
(0.43)\end{array}$ \\
\hline Time Diff. & & $\begin{array}{r}0.83 \\
(0.60)\end{array}$ & $\begin{array}{r}1.04 \\
(0.60)\end{array}$ & $\begin{array}{r}-0.43 \\
(0.60)\end{array}$ & $\begin{array}{r}-1.71 \\
(0.59)\end{array}$ & $\begin{array}{r}-2.43 \\
(0.59)\end{array}$ & $\begin{array}{r}-2.25 \\
(0.60)\end{array}$ & $\begin{array}{r}-2.24 \\
(0.61)\end{array}$ & $\begin{array}{r}-3.57 \\
(0.61)\end{array}$ \\
\hline Nondisabled workers & $\begin{array}{r}41.50 \\
(0.09)\end{array}$ & $\begin{array}{r}41.47 \\
(0.09)\end{array}$ & $\begin{array}{c}41.48 \\
(0.09)\end{array}$ & $\begin{array}{l}41.75 \\
(0.09)\end{array}$ & $\begin{array}{l}42.04 \\
(0.09)\end{array}$ & $\begin{array}{l}42.36 \\
(0.09)\end{array}$ & $\begin{array}{l}42.55 \\
(0.10)\end{array}$ & $\begin{array}{l}42.81 \\
(0.09)\end{array}$ & $\begin{array}{l}43.04 \\
(0.09)\end{array}$ \\
\hline Time Diff. & & $\begin{array}{r}-0.03 \\
(0.13)\end{array}$ & $\begin{array}{r}-0.02 \\
(0.13)\end{array}$ & $\begin{array}{r}0.25 \\
(0.13)\end{array}$ & $\begin{array}{r}0.54 \\
(0.13)\end{array}$ & $\begin{array}{r}0.86 \\
(0.13)\end{array}$ & $\begin{array}{r}1.05 \\
(0.13)\end{array}$ & $\begin{array}{r}1.31 \\
(0.13)\end{array}$ & $\begin{array}{r}1.54 \\
(0.13)\end{array}$ \\
\hline Group-Time Diff. & & $\begin{array}{r}0.86 \\
(0.61)\end{array}$ & $\begin{array}{r}1.05 \\
(0.61)\end{array}$ & $\begin{array}{r}-0.68 \\
(0.61)\end{array}$ & $\begin{array}{r}-2.25 \\
(0.60)\end{array}$ & $\begin{array}{r}-3.29 \\
(0.60)\end{array}$ & $\begin{array}{r}-3.30 \\
(0.61)\end{array}$ & $\begin{array}{r}-3.55 \\
(0.62)\end{array}$ & $\begin{array}{r}-5.11 \\
(0.62)\end{array}$ \\
\hline Group-Time-State Diff. & & $\begin{array}{r}\mathbf{- 1 . 9 8} \\
(0.73)\end{array}$ & $\begin{array}{r}\mathbf{- 2 . 1 7} \\
(0.73)\end{array}$ & $\begin{array}{r}\mathbf{- 0 . 7 4} \\
(0.73)\end{array}$ & $\begin{array}{l}\mathbf{0 . 6 2} \\
(0.72)\end{array}$ & $\begin{array}{r}\mathbf{1 . 2 6} \\
(0.72)\end{array}$ & $\begin{array}{c}\mathbf{0 . 8 0} \\
(0.74)\end{array}$ & $\begin{array}{r}\mathbf{0 . 3 5} \\
(0.74)\end{array}$ & $\begin{array}{l}\mathbf{1 . 0 0} \\
(0.74)\end{array}$ \\
\hline \multicolumn{10}{|c|}{ "No Protection" States versus "Protection Without Accommodation" States } \\
\hline & 88-89 & 90-91 & $91-92$ & $92-93$ & 93-94 & $94-95$ & $95-96$ & 96-97 & 97-98 \\
\hline \multicolumn{10}{|l|}{ No Protection States } \\
\hline Disabled workers & $\begin{array}{r}12.19 \\
(0.88)\end{array}$ & $\begin{array}{r}10.40 \\
(0.81)\end{array}$ & $\begin{array}{r}11.39 \\
(0.85)\end{array}$ & $\begin{array}{r}11.11 \\
(0.84)\end{array}$ & $\begin{array}{r}10.57 \\
(0.86)\end{array}$ & $\begin{array}{c}11.58 \\
(0.93)\end{array}$ & $\begin{array}{l}11.41 \\
(0.90)\end{array}$ & $\begin{array}{r}10.64 \\
(0.91)\end{array}$ & $\begin{array}{r}10.70 \\
(0.93)\end{array}$ \\
\hline Time Diff. & & $\begin{array}{r}-1.79 \\
(1.19)\end{array}$ & $\begin{array}{r}-0.80 \\
(1.23)\end{array}$ & $\begin{array}{r}-1.08 \\
(1.22)\end{array}$ & $\begin{array}{r}-1.62 \\
(1.23)\end{array}$ & $\begin{array}{r}-0.61 \\
(1.28)\end{array}$ & $\begin{array}{r}-0.78 \\
(1.26)\end{array}$ & $\begin{array}{r}-1.55 \\
(1.26)\end{array}$ & $\begin{array}{r}-1.49 \\
(1.28)\end{array}$ \\
\hline Nondisabled workers & $\begin{array}{l}39.89 \\
(0.27)\end{array}$ & $\begin{array}{c}39.96 \\
(0.26)\end{array}$ & $\begin{array}{l}40.22 \\
(0.26)\end{array}$ & $\begin{array}{l}40.34 \\
(0.27)\end{array}$ & $\begin{array}{l}40.75 \\
(0.27)\end{array}$ & $\begin{array}{l}41.01 \\
(0.28)\end{array}$ & $\begin{array}{l}41.55 \\
(0.28)\end{array}$ & $\begin{array}{l}41.94 \\
(0.28)\end{array}$ & $\begin{array}{l}42.03 \\
(0.28)\end{array}$ \\
\hline Time Diff. & & $\begin{array}{r}0.07 \\
(0.38)\end{array}$ & $\begin{array}{r}0.32 \\
(0.38)\end{array}$ & $\begin{array}{r}0.45 \\
(0.38)\end{array}$ & $\begin{array}{r}0.85 \\
(0.38)\end{array}$ & $\begin{array}{r}1.12 \\
(0.38)\end{array}$ & $\begin{array}{r}1.66 \\
(0.38)\end{array}$ & $\begin{array}{r}2.05 \\
(0.39)\end{array}$ & $\begin{array}{r}2.14 \\
(0.39)\end{array}$ \\
\hline Group-Time Diff. & & $\begin{array}{r}-1.85 \\
(1.25)\end{array}$ & $\begin{array}{r}-1.12 \\
(1.28)\end{array}$ & $\begin{array}{r}-1.53 \\
(1.27)\end{array}$ & $\begin{array}{r}-2.47 \\
(1.29)\end{array}$ & $\begin{array}{r}-1.73 \\
(1.33)\end{array}$ & $\begin{array}{r}-2.44 \\
(1.32)\end{array}$ & $\begin{array}{r}-3.60 \\
(1.32)\end{array}$ & $\begin{array}{r}-3.63 \\
(1.34)\end{array}$ \\
\hline \multicolumn{10}{|c|}{ Protection Without Accommodation States } \\
\hline Disabled workers & $\begin{array}{r}16.25 \\
(0.29)\end{array}$ & $\begin{array}{r}14.90 \\
(0.27)\end{array}$ & $\begin{array}{r}14.67 \\
(0.26)\end{array}$ & $\begin{array}{r}14.34 \\
(0.26)\end{array}$ & $\begin{array}{r}14.43 \\
(0.26)\end{array}$ & $\begin{array}{r}14.47 \\
(0.27)\end{array}$ & $\begin{array}{l}14.33 \\
(0.28)\end{array}$ & $\begin{array}{r}14.00 \\
(0.27)\end{array}$ & $\begin{array}{l}13.48 \\
(0.27)\end{array}$ \\
\hline Time Diff. & & $\begin{array}{r}-1.35 \\
(0.39)\end{array}$ & $\begin{array}{r}-1.57 \\
(0.39)\end{array}$ & $\begin{array}{r}-1.91 \\
(0.39)\end{array}$ & $\begin{array}{r}-1.82 \\
(0.39)\end{array}$ & $\begin{array}{r}-1.78 \\
(0.39)\end{array}$ & $\begin{array}{r}-1.92 \\
(0.40)\end{array}$ & $\begin{array}{r}-2.25 \\
(0.40)\end{array}$ & $\begin{array}{r}-2.77 \\
(0.40)\end{array}$ \\
\hline Nondisabled workers & $\begin{array}{l}40.68 \\
(0.06)\end{array}$ & $\begin{array}{l}40.45 \\
(0.06)\end{array}$ & $\begin{array}{l}40.23 \\
(0.06)\end{array}$ & $\begin{array}{l}40.19 \\
(0.06)\end{array}$ & $\begin{array}{l}40.48 \\
(0.07)\end{array}$ & $\begin{array}{l}40.94 \\
(0.07)\end{array}$ & $\begin{array}{l}41.26 \\
(0.07)\end{array}$ & $\begin{array}{l}41.64 \\
(0.07)\end{array}$ & $\begin{array}{l}42.02 \\
(0.07)\end{array}$ \\
\hline Time Diff. & & $\begin{array}{r}-0.23 \\
(0.09)\end{array}$ & $\begin{array}{r}-0.46 \\
(0.09)\end{array}$ & $\begin{array}{r}-0.49 \\
(0.09)\end{array}$ & $\begin{array}{r}-0.20 \\
(0.09)\end{array}$ & $\begin{array}{r}0.25 \\
(0.09)\end{array}$ & $\begin{array}{r}0.58 \\
(0.09)\end{array}$ & $\begin{array}{r}0.96 \\
(0.09)\end{array}$ & $\begin{array}{r}1.34 \\
(0.09)\end{array}$ \\
\hline Group-Time Diff. & & $\begin{array}{r}-1.12 \\
(0.40)\end{array}$ & $\begin{array}{r}-1.12 \\
(0.40)\end{array}$ & $\begin{array}{r}-1.42 \\
(0.40)\end{array}$ & $\begin{array}{r}-1.62 \\
(0.40)\end{array}$ & $\begin{array}{r}-2.03 \\
(0.41)\end{array}$ & $\begin{array}{r}-2.50 \\
(0.41)\end{array}$ & $\begin{array}{r}-3.21 \\
(0.41)\end{array}$ & $\begin{array}{r}-4.10 \\
(0.41)\end{array}$ \\
\hline Group-Time-State Diff. & & $\begin{array}{r}\mathbf{- 0 . 7 3} \\
(1.31)\end{array}$ & $\begin{array}{r}\mathbf{- 0 . 0 1} \\
(1.34)\end{array}$ & $\begin{array}{r}\mathbf{- 0 . 1 1} \\
(1.33)\end{array}$ & $\begin{array}{r}\mathbf{- 0 . 8 5} \\
(1.35)\end{array}$ & $\begin{array}{c}\mathbf{0 . 3 0} \\
(1.39)\end{array}$ & $\begin{array}{c}\mathbf{0 . 0 6} \\
(1.38)\end{array}$ & $\begin{array}{r}\mathbf{- 0 . 4 0} \\
(1.38)\end{array}$ & $\begin{array}{c}\mathbf{0 . 4 8} \\
(1.40)\end{array}$ \\
\hline
\end{tabular}

Notes: Means reflect average weeks worked by state group, category of worker (disabled versus nondisabled), and time period. All estimates are weighted using CPS survey weights. Standard errors are reported beneath mean estimates. See Tables 1 and 2 and the text for the states in each group. 
Table 5: Basic Regression Results

\begin{tabular}{|c|c|c|c|c|c|c|c|c|}
\hline Basic Specification & 90-91 & 91-92 & $92-93$ & 93-94 & 94-95 & $95-96$ & 96-97 & $97-98$ \\
\hline Coeff. on ADA*DIS & $\begin{array}{c}1.23 \\
(0.63) \\
{[0.93]}\end{array}$ & $\begin{array}{c}1.67 \\
(0.78) \\
{[0.96]}\end{array}$ & $\begin{array}{l}0.51 \\
(0.51) \\
{[0.98]}\end{array}$ & $\begin{array}{l}-0.99 \\
(0.52) \\
{[0.88]}\end{array}$ & $\begin{array}{l}-1.92 \\
(0.49) \\
{[0.82]}\end{array}$ & $\begin{array}{l}-1.46 \\
(0.61) \\
{[0.92]}\end{array}$ & $\begin{array}{l}-1.23 \\
(0.70) \\
{[0.93]}\end{array}$ & $\begin{array}{l}-2.67 \\
(0.58) \\
{[0.88]}\end{array}$ \\
\hline Coeff. on ADA*DIS*LP & $\begin{array}{l}-2.14 \\
(0.69) \\
{[1.07]}\end{array}$ & $\begin{array}{l}-2.51 \\
(0.73) \\
{[1.04]}\end{array}$ & $\begin{array}{l}-1.54 \\
(0.68) \\
{[1.10]}\end{array}$ & $\begin{array}{l}-0.08 \\
(0.76) \\
{[1.04]}\end{array}$ & $\begin{array}{c}0.70 \\
(0.68) \\
{[0.98]}\end{array}$ & $\begin{array}{c}0.12 \\
(0.79) \\
{[1.05]}\end{array}$ & $\begin{array}{l}-0.60 \\
(0.88) \\
{[1.07]}\end{array}$ & $\begin{array}{c}0.02 \\
(0.74) \\
{[0.99]}\end{array}$ \\
\hline Coeff. on ADA $*$ DIS $*$ NP & $\begin{array}{l}-2.63 \\
(0.86) \\
{[1.21]}\end{array}$ & $\begin{array}{l}-1.96 \\
(0.94) \\
{[1.24]}\end{array}$ & $\begin{array}{l}-1.12 \\
(0.87) \\
{[1.23]}\end{array}$ & $\begin{array}{l}-0.37 \\
(1.22) \\
{[1.19]}\end{array}$ & $\begin{array}{c}1.57 \\
(1.44) \\
{[1.33]}\end{array}$ & $\begin{array}{c}0.44 \\
(1.19) \\
{[1.30]}\end{array}$ & $\begin{array}{l}-0.56 \\
(0.87) \\
{[1.05]}\end{array}$ & $\begin{array}{c}0.24 \\
(0.68) \\
{[1.07]}\end{array}$ \\
\hline $\begin{array}{l}\text { Coeff. on ADA*DIS*NP - } \\
\text { Coeff. on ADA*DIS*LP }\end{array}$ & $\begin{array}{l}-0.49 \\
(0.71) \\
{[0.98]}\end{array}$ & $\begin{array}{l}0.55 \\
(0.76) \\
{[0.57]}\end{array}$ & $\begin{array}{c}0.42 \\
(0.96) \\
{[0.98]}\end{array}$ & $\begin{array}{l}-0.25 \\
(1.24) \\
{[1.00]}\end{array}$ & $\begin{array}{c}0.87 \\
(1.38) \\
{[1.17]}\end{array}$ & $\begin{array}{c}0.32 \\
(1.11) \\
{[1.07]}\end{array}$ & $\begin{array}{c}0.04 \\
(0.80) \\
{[0.76]}\end{array}$ & $\begin{array}{c}0.22 \\
(0.68) \\
{[0.82]}\end{array}$ \\
\hline $\begin{array}{c}\text { Specification with State, } \\
\text { Year, and State*Year } \\
\text { Fixed Effects }\end{array}$ & $90-91$ & 91-92 & $92-93$ & 93-94 & 94-95 & $95-96$ & 96-97 & $97-98$ \\
\hline Coeff. on ADA*DIS & $\begin{array}{l}1.33 \\
(0.77) \\
{[0.59]}\end{array}$ & $\begin{array}{l}1.72 \\
(0.82) \\
{[0.72]}\end{array}$ & $\begin{array}{l}0.55 \\
(0.80) \\
{[0.43]}\end{array}$ & $\begin{array}{l}-0.96 \\
(0.69) \\
{[0.48]}\end{array}$ & $\begin{array}{l}-1.89 \\
(0.67) \\
{[0.48]}\end{array}$ & $\begin{array}{l}-1.41 \\
(0.77) \\
{[0.58]}\end{array}$ & $\begin{array}{l}-1.19 \\
(0.79) \\
{[0.70]}\end{array}$ & $\begin{array}{l}-2.68 \\
(0.74) \\
{[0.50]}\end{array}$ \\
\hline Coeff. on ADA*DIS*LP & $\begin{array}{l}-2.22 \\
(0.84) \\
{[0.62]}\end{array}$ & $\begin{array}{l}-2.56 \\
(0.85) \\
{[0.63]}\end{array}$ & $\begin{array}{l}-1.54 \\
(0.88) \\
{[0.50]}\end{array}$ & $\begin{array}{l}-0.06 \\
(0.81) \\
{[0.64]}\end{array}$ & $\begin{array}{l}0.76 \\
(0.79) \\
{[0.57]}\end{array}$ & $\begin{array}{l}0.14 \\
(0.88) \\
{[0.69]}\end{array}$ & $\begin{array}{l}-0.61 \\
(0.89) \\
{[0.78]}\end{array}$ & $\begin{array}{l}0.11 \\
(0.81) \\
{[0.58]}\end{array}$ \\
\hline Coeff. on ADA*DIS*NP & $\begin{array}{l}-2.76 \\
(0.96) \\
{[0.66]}\end{array}$ & $\begin{array}{l}-2.03 \\
(1.07) \\
{[0.82]}\end{array}$ & $\begin{array}{l}-1.17 \\
(1.05) \\
{[0.79]}\end{array}$ & $\begin{array}{l}-0.36 \\
(1.06) \\
{[1.18]}\end{array}$ & $\begin{array}{l}1.59 \\
(1.22) \\
{[1.49]}\end{array}$ & $\begin{array}{l}0.44 \\
(1.21) \\
{[1.07]}\end{array}$ & $\begin{array}{l}-0.55 \\
(0.90) \\
{[0.78]}\end{array}$ & $\begin{array}{l}0.27 \\
(0.90) \\
{[0.52]}\end{array}$ \\
\hline $\begin{array}{l}\text { Coeff. on ADA*DIS*NP - } \\
\text { Coeff. on ADA*DIS*LP }\end{array}$ & $\begin{array}{l}-0.53 \\
(0.69) \\
{[0.44]}\end{array}$ & $\begin{array}{c}0.53 \\
(0.65) \\
{[0.60]}\end{array}$ & $\begin{array}{c}0.37 \\
(0.88) \\
{[0.85]}\end{array}$ & $\begin{array}{l}-0.30 \\
(0.94) \\
{[1.17]}\end{array}$ & $\begin{array}{c}0.83 \\
(1.11) \\
{[1.42]}\end{array}$ & $\begin{array}{c}0.29 \\
(1.05) \\
{[0.95]}\end{array}$ & $\begin{array}{l}0.06 \\
(0.65) \\
{[0.57]}\end{array}$ & $\begin{array}{c}0.16 \\
(0.68) \\
{[0.48]}\end{array}$ \\
\hline
\end{tabular}

\begin{tabular}{cccccccccc}
\hline \hline $\begin{array}{c}\text { Specification Omitting State- } \\
\text { Law Variables, but Including } \\
\text { State, Ye ar, and State*Year } \\
\text { Fixed Effects }\end{array}$ & $\mathbf{9 0 - 9 1}$ & $\mathbf{9 1 - 9 2}$ & $\mathbf{9 2 - 9 3}$ & $\mathbf{9 3 - 9 4}$ & $\mathbf{9 4 - 9 5}$ & $\mathbf{9 5 - 9 6}$ & $\mathbf{9 6 - 9 7}$ & $\mathbf{9 7 - 9 8}$ \\
\hline Coeff. on ADA*DIS & & & & & & & & \\
& -0.14 & 0.24 & -0.29 & -0.94 & -1.29 & -1.29 & -1.65 & -2.65 \\
& $(0.39)$ & $(0.48)$ & $(0.47)$ & $(0.37)$ & $(0.34)$ & $(0.36)$ & $(0.38)$ & $(0.36)$ \\
& {$[0.37]$} & {$[0.53]$} & {$[0.46]$} & {$[0.36]$} & {$[0.28]$} & {$[0.32]$} & {$[0.33]$} & {$[0.33]$} \\
\hline \hline No. of Observations & 292,562 & 291,149 & 286,796 & 283,860 & 274,988 & 265,866 & 266,478 & 266,838 \\
\hline
\end{tabular}

Notes: The dependent variable is weeks worked per year. The pre-ADA period is 1988-1989. The post-ADA period is as stated. Robust standard errors clustered on state-disability interactions are in parentheses below coefficient estimates, and robust standard errors clustered on state-disability-year interactions are in square brackets below coefficient estimates. All regressions are OLS regressions, employ CPS survey weights, and include the individual control variables listed in the text plus controls for state unemployment rate (in regressions without state, year, and state*year fixed effects) and the interaction of disability and state unemployment rate. See equation (1) for further details. 
Table 6: Robustness Checks

\begin{tabular}{|c|c|c|c|c|c|c|c|}
\hline \multicolumn{4}{|c|}{$\begin{array}{l}\text { (1) Sample Includes Only Observations } \\
\text { from Pre-1980 Enactors }\end{array}$} & \multicolumn{4}{|c|}{$\begin{array}{l}\text { (2) Sample Includes Only Observations from } \\
\text { High-Employer-Size-Thres hold States }\end{array}$} \\
\hline & $90-91$ & 91-92 & $92-93$ & & $90-91$ & 91-92 & $92-93$ \\
\hline Coeff. on ADA*DIS & $\begin{array}{l}2.95 \\
(1.29) \\
{[0.74]}\end{array}$ & $\begin{array}{l}2.65 \\
(1.75) \\
{[1.99]}\end{array}$ & $\begin{array}{c}-0.17 \\
(2.17) \\
{[1.00]}\end{array}$ & Coeff. on ADA*DIS & $\begin{array}{c}0.48 \\
(0.93) \\
{[1.25]}\end{array}$ & $\begin{array}{l}1.14 \\
(0.73) \\
{[0.97]}\end{array}$ & $\begin{array}{c}0.99 \\
(0.87) \\
{[0.70]}\end{array}$ \\
\hline Coeff. on ADA*DIS*LP & $\begin{array}{c}-3.80 \\
(1.37) \\
{[0.85]}\end{array}$ & $\begin{array}{l}-3.54 \\
(1.79) \\
{[2.02]}\end{array}$ & $\begin{array}{l}-1.07 \\
(2.25) \\
{[1.12]}\end{array}$ & Coeff. on ADA*DIS*LP & $\begin{array}{c}-1.40 \\
(1.16) \\
{[1.39]}\end{array}$ & $\begin{array}{l}-2.47 \\
(0.99) \\
{[1.10]}\end{array}$ & $\begin{array}{c}-1.93 \\
(1.16) \\
{[1.11]}\end{array}$ \\
\hline Coeff. on ADA*DIS*NP & $\begin{array}{c}-4.38 \\
(1.41) \\
{[0.79]}\end{array}$ & $\begin{array}{l}-2.97 \\
(1.88) \\
{[2.03]}\end{array}$ & $\begin{array}{l}-0.43 \\
(2.27) \\
{[1.20]}\end{array}$ & Coeff. on ADA*DIS*NP & $\begin{array}{c}-1.93 \\
(1.11) \\
{[1.30]}\end{array}$ & $\begin{array}{l}-1.52 \\
(1.02) \\
{[1.07]}\end{array}$ & $\begin{array}{c}-1.62 \\
(1.11) \\
{[0.98]}\end{array}$ \\
\hline $\begin{array}{l}\text { Coeff. on ADA*DIS*NP - } \\
\text { Coeff. on ADA*DIS*LP }\end{array}$ & $\begin{array}{c}-0.58 \\
(0.70) \\
{[0.48]}\end{array}$ & $\begin{array}{l}0.58 \\
(0.86) \\
{[0.66]}\end{array}$ & $\begin{array}{c}0.64 \\
(0.97) \\
{[0.96]}\end{array}$ & $\begin{array}{l}\text { Coeff. on ADA*DIS*NP - } \\
\text { Coeff. on ADA*DIS*LP }\end{array}$ & $\begin{array}{c}-0.53 \\
(0.93) \\
{[0.71]}\end{array}$ & $\begin{array}{l}0.95 \\
(1.00) \\
{[0.75]}\end{array}$ & $\begin{array}{l}0.31 \\
(1.04) \\
{[1.11]}\end{array}$ \\
\hline No. of Observations & 192,885 & 191,815 & 188,956 & No. of Observations & 93,566 & 92,864 & 91,464 \\
\hline \multicolumn{4}{|c|}{$\begin{array}{l}\text { (3) Specification with State-Level Dis ability } \\
\text { Bene fits Receipt Information }\end{array}$} & \multicolumn{4}{|c|}{$\begin{array}{l}\text { (4) Specification with State-Level Dis ability } \\
\text { Benefits Application Information }\end{array}$} \\
\hline & $90-91$ & 91-92 & $92-93$ & & $90-91$ & 91-92 & $92-93$ \\
\hline Coeff. on ADA*DIS & $\begin{array}{c}1.00 \\
(0.78) \\
{[0.70]}\end{array}$ & $\begin{array}{c}1.28 \\
(0.85) \\
{[0.81]}\end{array}$ & $\begin{array}{c}0.68 \\
(0.85) \\
{[0.59]}\end{array}$ & Coeff. on ADA $*$ DIS & $\begin{array}{c}1.45 \\
(0.79) \\
{[0.69]}\end{array}$ & $\begin{array}{l}1.95 \\
(0.86) \\
{[0.81]}\end{array}$ & $\begin{array}{c}1.23 \\
(0.88) \\
{[0.68]}\end{array}$ \\
\hline Coeff. on ADA*DIS*LP & $\begin{array}{l}-2.03 \\
(0.88) \\
{[0.76]}\end{array}$ & $\begin{array}{l}-2.41 \\
(0.90) \\
{[0.74]}\end{array}$ & $\begin{array}{l}-1.43 \\
(0.91) \\
{[0.54]}\end{array}$ & Coeff. on ADA*DIS*LP & $\begin{array}{l}-1.78 \\
(0.87) \\
{[0.76]}\end{array}$ & $\begin{array}{l}-1.99 \\
(0.88) \\
{[0.74]}\end{array}$ & $\begin{array}{l}-0.92 \\
(0.91) \\
{[0.62]}\end{array}$ \\
\hline Coeff. on ADA*DIS*NP & $\begin{array}{l}-2.54 \\
(1.61) \\
{[0.75]}\end{array}$ & $\begin{array}{c}-1.55 \\
(1.67) \\
{[0.81]}\end{array}$ & $\begin{array}{c}-0.01 \\
(1.38) \\
{[0.79]}\end{array}$ & Coeff. on ADA*DIS*NP & $\begin{array}{c}-1.82 \\
(1.87) \\
{[0.81]}\end{array}$ & $\begin{array}{c}-0.68 \\
(1.89) \\
{[0.79]}\end{array}$ & $\begin{array}{c}0.93 \\
(1.67) \\
{[1.01]}\end{array}$ \\
\hline $\begin{array}{l}\text { Coeff. on ADA*DIS*NP - } \\
\text { Coeff. on ADA*DIS*LP }\end{array}$ & $\begin{array}{c}0.50 \\
(1.46) \\
{[0.43]}\end{array}$ & $\begin{array}{c}0.86 \\
(1.52) \\
{[0.53]}\end{array}$ & $\begin{array}{c}1.42 \\
(1.23) \\
{[0.74]}\end{array}$ & $\begin{array}{l}\text { Coeff. on ADA*DIS*NP - } \\
\text { Coeff. on ADA*DIS*LP }\end{array}$ & $\begin{array}{c}-0.03 \\
(1.73) \\
{[0.55]}\end{array}$ & $\begin{array}{l}1.31 \\
(1.77) \\
{[0.67]}\end{array}$ & $\begin{array}{c}1.85 \\
(1.57) \\
{[1.00]}\end{array}$ \\
\hline No. of Observations & 292,562 & 291,149 & 286,796 & No. of Observations & 292,562 & 291,149 & 286,796 \\
\hline
\end{tabular}

Notes: The dependent variable is weeks worked per year. The pre-ADA period is 1988-1989. The post-ADA period is as stated. Robust standard errors clustered on state-disability interactions are in parentheses below coefficient estimates, and robust standard errors clustered on state-disability-year interactions are in square brackets below coefficient estimates. All regressions are OLS regressions, employ CPS survey weights, and include state, year, and state*year fixed effects. Control variables are as stated in Table 5. In the upper panel of the present table, columns (1)(3) use observations from states in which the state-level pre-ADA disability discrimination regime was in place prior to 1980; columns (4)-(6) use observations from states with ADA-like employer-size thresholds. See Tables 1 and 2 for details on employer-size thresholds; observations from Tennessee and Virginia, whose pre-ADA statutory and judicial law did not specify an employer-size threshold, are not included in the samples used in column (4)-(6). In the lower panel, columns (1)-(3) replace individual receipt of disability benefits with the percent of the state population receiving disability benefits interacted with disability status; columns (4)-(6) replace individual receipt of disability benefits with the percent of the state population applying for disability benefits interacted with disability status. Fixed effects included in these regressions preclude inclusion of the percent of the state population receiving or applying for disability benefits alone. 
Figure 1: Percentage of Individuals Reporting Disability By State Group

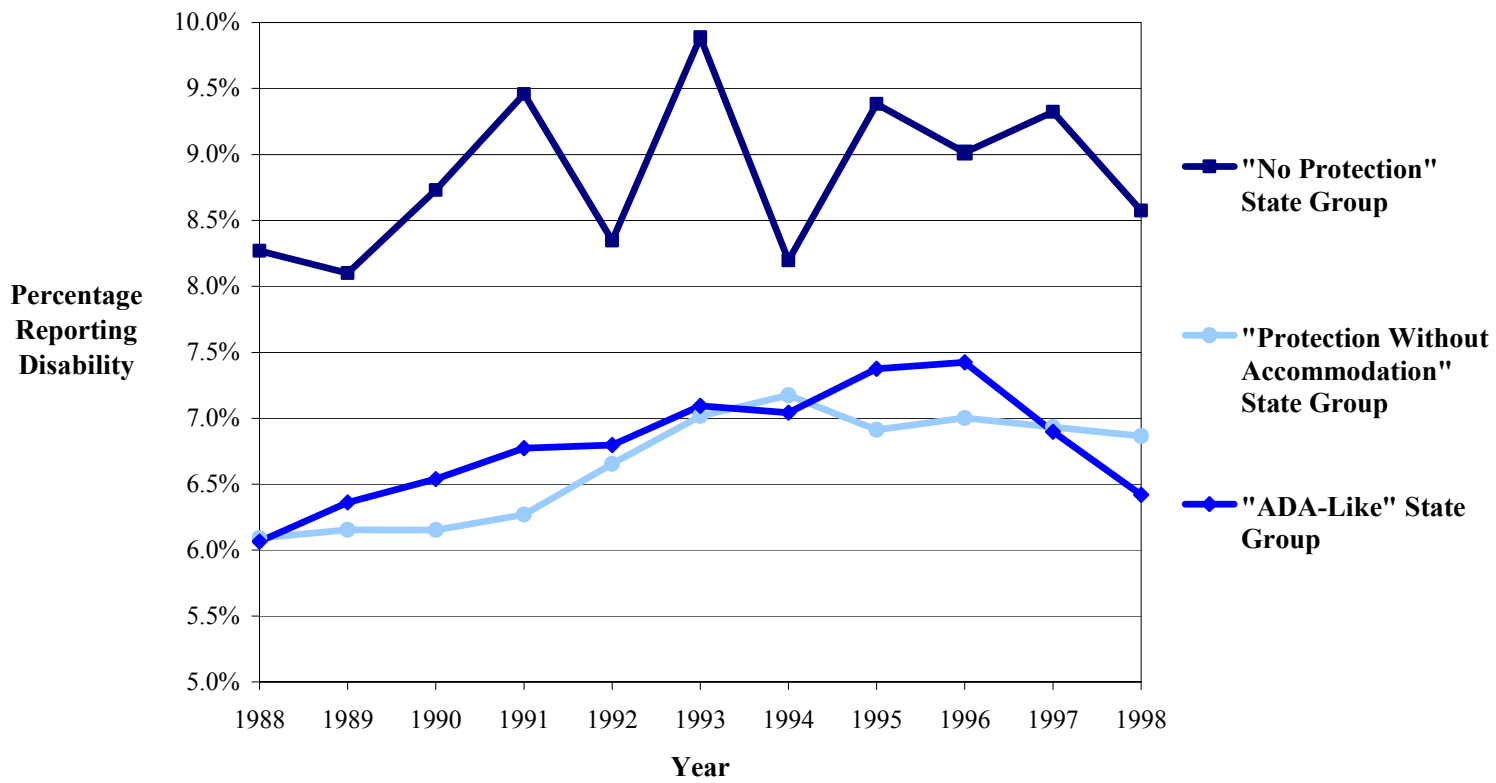

Figure 2: Percentage of Individuals Reporting Disability By State Group - Trendlines

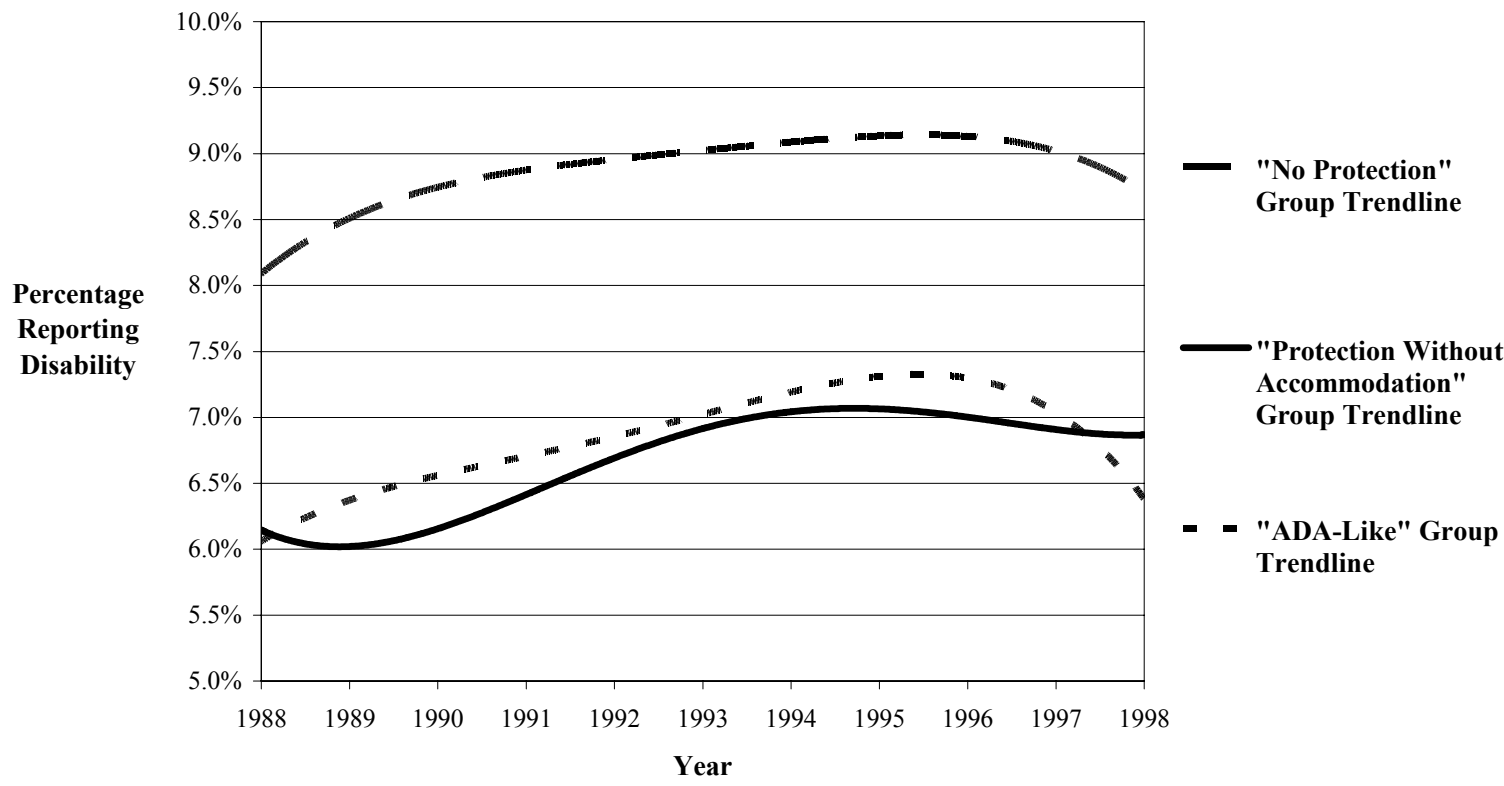

Note: All trendlines are fourth-order polynomials. 
Figure 3: "ADA-Like" and "Protection Without Accommodation" State Disabled Employment Trends

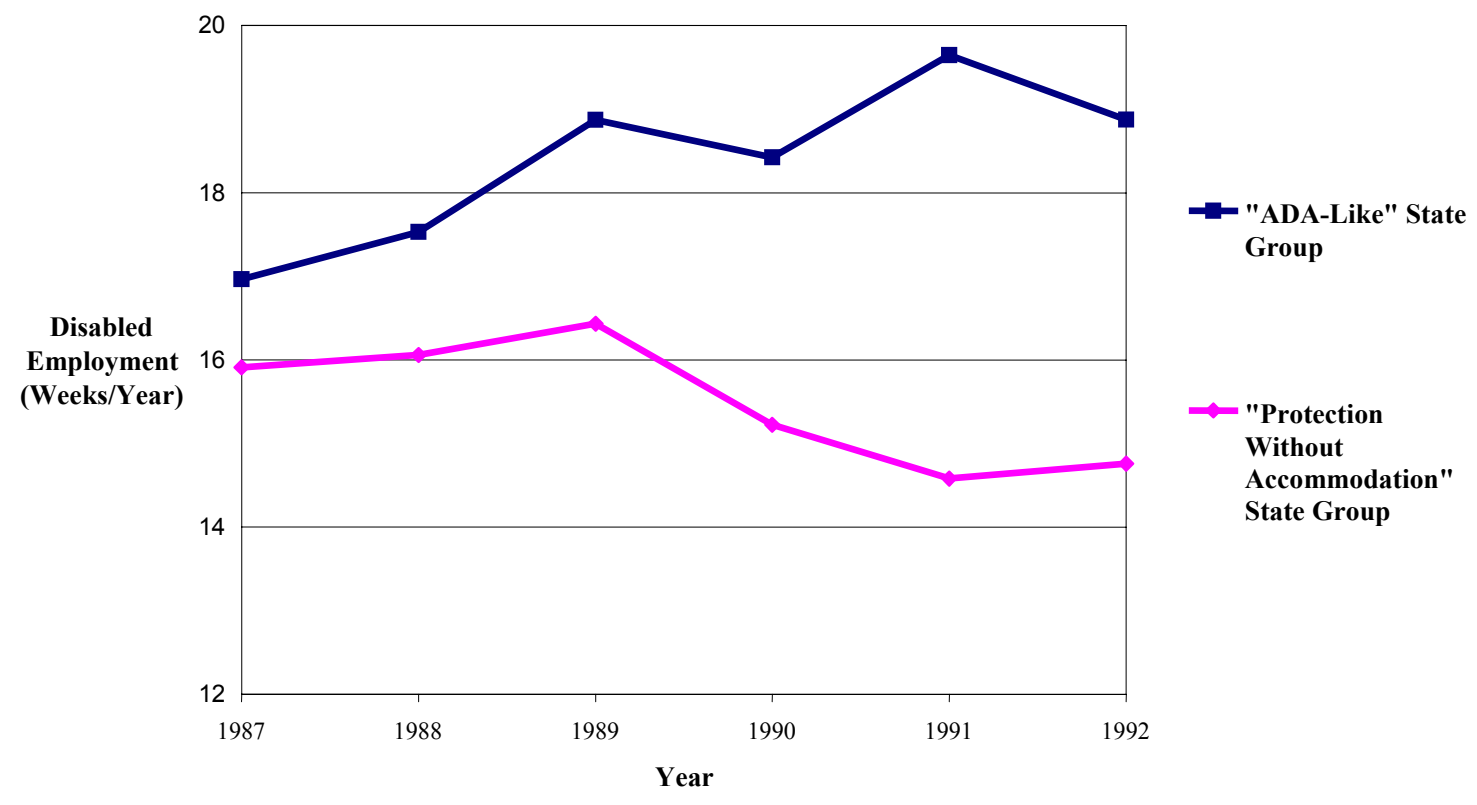

Figure 4: "ADA-Like" and "Protection Without Accommodation" State Disabled Employment Trendlines

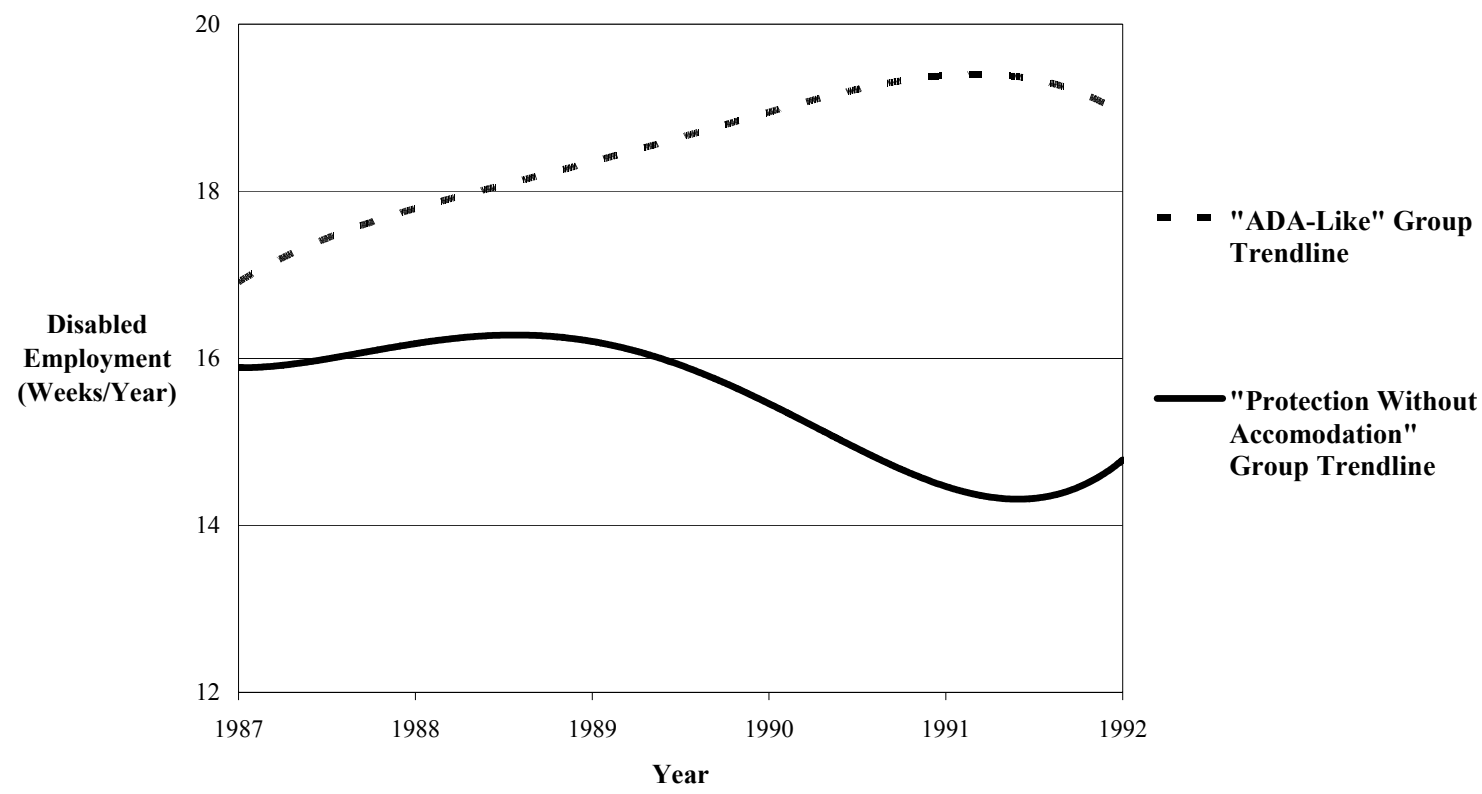

Note: All trendlines are fourth-order polynomials. 


\section{Table A1: Pre-ADA State Laws Prohibiting Disability Discrimination by Private Employers - Original Statutory Sections and Substantive Pre-ADA Amendments}

\begin{tabular}{|c|c|c|c|}
\hline \multirow{2}{*}{$\begin{array}{c}\text { Protection } \\
\text { Without } \\
\text { Accommodation } \\
\text { States }\end{array}$} & \multirow{2}{*}{$\begin{array}{l}\text { Original Statutory } \\
\quad \text { Section(s) }\end{array}$} & \multicolumn{2}{|c|}{ Substantive Pre-ADA Amendments } \\
\hline & & $\begin{array}{c}\text { Date of } \\
\text { Amendment(s) }\end{array}$ & $\begin{array}{l}\text { Nature of } \\
\text { Amendment(s) }\end{array}$ \\
\hline Alaska & 18.80.220(1) & 1987 & $\begin{array}{l}\text { Broadened coverage to mental as well } \\
\text { as physical disability }\end{array}$ \\
\hline California & Lab. 1420(a) & 1975 & $\begin{array}{l}\text { Broadened coverage to "medical } \\
\text { conditions" as well as physical } \\
\text { disability }\end{array}$ \\
\hline Connecticut & $31-126(a)$ & $1978 ; 1979$ & $\begin{array}{l}\text { Broadened coverage to mental } \\
\text { retardation (1978) and mental disorders } \\
\text { (1979) as well as physical disability }\end{array}$ \\
\hline Florida & $\begin{array}{c}\text { 13-261(1) } \\
\text { (later 23.167(1)) }\end{array}$ & $\mathrm{n} / \mathrm{a}$ & $\mathrm{n} / \mathrm{a}$ \\
\hline Hawaii & $\mathrm{n} / \mathrm{a}$ & 1981 & Broadened scope of liability \\
\hline Illinois & $\begin{array}{l}\text { 38:65-23(1) (later 48- } \\
\text { 853-3(a)) }\end{array}$ & $\mathrm{n} / \mathrm{a}$ & $\mathrm{n} / \mathrm{a}$ \\
\hline Maryland & 49B:19(a) & $\mathrm{n} / \mathrm{a}$ & $\mathrm{n} / \mathrm{a}$ \\
\hline Michigan & $\mathrm{n} / \mathrm{a}$ & 1980 & Broadened scope of liability \\
\hline Missouri & $296.020(1)$ & $\mathrm{n} / \mathrm{a}$ & $\mathrm{n} / \mathrm{a}$ \\
\hline Montana & $\begin{array}{l}1974 \text { S.L. ch. } 77 \text {, sec. } 3 \\
\quad \text { (later } 64-306(a))\end{array}$ & 1975 & $\begin{array}{l}\text { Broadened coverage to mental as well } \\
\text { as physical disability and broadened } \\
\text { scope of liability }\end{array}$ \\
\hline Nevada & $\mathrm{n} / \mathrm{a}$ & $1973 ; 1981$ & $\begin{array}{l}\text { Added protection for use of guide dogs } \\
\text { (1973); broadened coverage to "aural" } \\
\text { as well as "physical" and "visual" } \\
\text { handicaps (1981) }\end{array}$ \\
\hline New Jersey & $\mathrm{n} / \mathrm{a}$ & 1978 & $\begin{array}{l}\text { Broadened coverage to mental as well } \\
\text { as physical disability and broadened } \\
\text { scope of liability }\end{array}$ \\
\hline Tennessee & $\mathrm{n} / \mathrm{a}$ & $1986 ; 1987$ & $\begin{array}{l}\text { Broadened scope of liability (1986); } \\
\text { corrected omission of private employers } \\
\text { from } 1986 \text { amendment (1987) }\end{array}$ \\
\hline Texas & $\begin{array}{l}\text { Art. } 4419 \mathrm{e}(\mathrm{f}) \text { (later Hum. } \\
\text { Res. Code 121.003(f)) }\end{array}$ & 1983 & Broadened scope of liability \\
\hline West Virginia & $5-11-9(a)$ & $\mathrm{n} / \mathrm{a}$ & $\mathrm{n} / \mathrm{a}$ \\
\hline
\end{tabular}

(continues on next page) 


\section{Table A1 (Continued): Pre-ADA State Laws Prohibiting Disability Discrimination by Private Employers - Original Statutory Sections and Substantive Pre-ADA Amendments}

\begin{tabular}{|c|c|c|c|}
\hline \multirow{2}{*}{$\begin{array}{c}\text { "ADA-Like" } \\
\text { States }\end{array}$} & \multirow{2}{*}{$\begin{array}{l}\text { Original Statutory } \\
\quad \text { Section(s) }\end{array}$} & \multicolumn{2}{|c|}{ Substantive Pre-ADA Amendments } \\
\hline & & $\begin{array}{c}\text { Date of } \\
\text { Amendment(s) }\end{array}$ & $\begin{array}{c}\text { Nature of } \\
\text { Amendment(s) }\end{array}$ \\
\hline Colorado & $24-34-306(1)(a)$ & $\mathrm{n} / \mathrm{a}$ & $\mathrm{n} / \mathrm{a}$ \\
\hline Iowa & 105A.7(1)(a) & $\mathrm{n} / \mathrm{a}$ & $\mathrm{n} / \mathrm{a}$ \\
\hline Massachusetts & $149: 24 \mathrm{~K}$ & 1983 & Broadened scope of liability \\
\hline Minnesota & $\mathrm{n} / \mathrm{a}$ & $1987 ; 1989$ & $\begin{array}{l}\text { Altered definition of "undue hardship" } \\
\text { (1987); refined definition of } \\
\text { reasonable accommodations (1989) }\end{array}$ \\
\hline New Mexico & $4-33-7(\mathrm{~A})$ & 1987 & $\begin{array}{l}\text { Broadened coverage to "medical } \\
\text { conditions" as well as physical and } \\
\text { mental disabilities }\end{array}$ \\
\hline North Carolina & $168-6$ & 1985 & $\begin{array}{l}\text { Made various revisions to liability } \\
\text { provisions }\end{array}$ \\
\hline Oregon & $\mathrm{n} / \mathrm{a}$ & 1979 & Broadened scope of liability \\
\hline Rhode Island & $28-5-7(\mathrm{~A})$ & 1981 & $\begin{array}{l}\text { Broadened coverage to mental as well } \\
\text { as physical disability }\end{array}$ \\
\hline Vermont & 21:498(a) & $\mathrm{n} / \mathrm{a}$ & $\mathrm{n} / \mathrm{a}$ \\
\hline Virginia & $\begin{array}{l}\text { 40.1-28.7 (later 51.01- } \\
\quad 41(\mathrm{~A}),(\mathrm{C}))\end{array}$ & $\mathrm{n} / \mathrm{a}$ & $\mathrm{n} / \mathrm{a}$ \\
\hline Wisconsin & $\begin{array}{l}\text { 111.32(5)(a), 111.36(4) } \\
\quad \text { (later 111.325) }\end{array}$ & $1967 ; 1975 ; 1981$ & $\begin{array}{l}\text { Rephrased and clarified prohibitions } \\
(1967,1975,1981)\end{array}$ \\
\hline
\end{tabular}

Notes: The original statutory section often differs from the source reported in Tables 1 and 2 because states frequently renumbered their statutes in this period. The substantive amendments reported in this table are amendments to pre-ADA statutory sections imposing traditional antidiscrimination prohibitions or reasonable accommodations requirements, and do not reflect changes in other statutory sections of states' disability discrimination laws. 


\section{Table A2: Effects of Alternative Characterizations of Pre-ADA State Laws Prohibiting Disability Discrimination by Private Employers}

\begin{tabular}{|c|c|c|}
\hline State & Legal Description & $\begin{array}{l}\text { Effect on Results for Post-ADA } \\
\text { Years 90-91, 91-92, and 92-93 }\end{array}$ \\
\hline California & $\begin{array}{l}\text { Prior to } 1981 \text {, Cal. Govt. } \S 12994 \text { expressly } \\
\text { stated that accommodations were not required. } \\
\text { In 1981, the section was amended to provide that } \\
\text { an employer shall not be required "to make any } \\
\text { accommodation for an employee who has a } \\
\text { physical handicap that would produce undue } \\
\text { hardship to the employer." There is no pre-ADA } \\
\text { caselaw indicating whether the } 1981 \text { amendment } \\
\text { was meant to impose affirmatively a requirement } \\
\text { of reasonable accommodations unless such } \\
\text { accommodations would be an undue hardship. }\end{array}$ & $\begin{array}{l}\text { Categorizing California as an "ADA-like" state, } \\
\text { rather than a "protection without accommodation" } \\
\text { state, does not alter the basic pattern of our results. } \\
\text { Our estimates of } \beta_{l 1} \text { (the effect of imposing a } \\
\text { reasonable accommodations requirement) are } \\
\text { somewhat smaller in magnitude and slightly less } \\
\text { precise. Our estimates of } \beta_{l 2}-\beta_{l l} \text { (the effect of } \\
\text { imposing a traditional antidiscrimination provision) } \\
\text { remain insignificant in all years. }\end{array}$ \\
\hline Delaware & $\begin{array}{l}\text { Law prohibiting disability discrimination by } \\
\text { private employers was not enacted until } 1988 \text {. }\end{array}$ & $\begin{array}{l}\text { Categorizing Delaware as a "no protection" state, } \\
\text { rather than an "ADA-like" state, has virtually no } \\
\text { effect on our estimates of } \beta_{11} \text { (the effect of imposing } \\
\text { a reasonable accommodations requirement). Our } \\
\text { estimates of } \beta_{12}-\beta_{l 1} \text { (the effect of imposing a } \\
\text { traditional antidiscrimination provision) remain } \\
\text { insignificant in all years. }\end{array}$ \\
\hline Idaho & $\begin{array}{l}\text { Law prohibiting disability discrimination by } \\
\text { private employers was not enacted until } 1988 \text {, } \\
\text { and the statutory language is somewhat } \\
\text { ambiguous as to the existence of a reasonable } \\
\text { accommodations requirement. }\end{array}$ & $\begin{array}{l}\text { Categorizing Idaho as a "no protection" state or a } \\
\text { "protection without accommodation" state, rather } \\
\text { than an "ADA-like" state, has virtually no effect on } \\
\text { our estimates of } \beta_{l l} \text { (the effect of imposing a } \\
\text { reasonable accommodations requirement). Our } \\
\text { estimates of } \beta_{l 2}-\beta_{l 1} \text { (the effect of imposing a } \\
\text { traditional antidiscrimination provision) remain } \\
\text { insignificant in all years. }\end{array}$ \\
\hline Iowa & $\begin{array}{l}\text { The Iowa Supreme Court adopted a reasonable } \\
\text { accommodations requirement in } 1987 \text { as a } \\
\text { freestanding interpretation of the statutory } \\
\text { language, but earlier courts had mentioned and } \\
\text { applied administrative regulations requiring } \\
\text { reasonable accommodations. }\end{array}$ & $\begin{array}{l}\text { This change cannot affect our results (because the } \\
\text { timing of state law adoption does not enter into our } \\
\text { categorization of states). }\end{array}$ \\
\hline Michigan & $\begin{array}{l}\text { Limited accommodation provision, not expressly } \\
\text { requiring reasonable accommodations, was } \\
\text { adopted in 1976. Administrative decisional law, } \\
\text { summarized in Wardlow v. Great Lakes Express } \\
\text { Co., } 339 \text { N.W.2d } 670 \text { (Mich. Ct. App. 1983), } \\
\text { adopted a reasonable accommodations } \\
\text { requirement, but in } 1986 \text { the Michigan Supreme } \\
\text { Court, in Carr v. General Motors Corp., } 389 \\
\text { N.W.2d } 686 \text { (Mich. 1986), adopted a conception } \\
\text { of the Michigan statute inconsistent with the } \\
\text { administrative decisional law's reasonable } \\
\text { accommodations requirement. }\end{array}$ & $\begin{array}{l}\text { Categorizing Michigan as an "ADA-like" state, } \\
\text { rather than a "protection without accommodation" } \\
\text { state, reduces the absolute magnitude of our } \\
\text { estimates of } \beta_{l 1} \text { (the effect of imposing a reasonable } \\
\text { accommodations requirement) by about } 10 \% \text {, while } \\
\text { the precision of the estimates generally improves. } \\
\text { Our estimates of } \beta_{12}-\beta_{1 I} \text { (the effect of imposing a } \\
\text { traditional antidiscrimination provision) remain } \\
\text { insignificant in all years. }\end{array}$ \\
\hline
\end{tabular}




\section{Table A2 (continued): Effects of Alternative Characterizations of Pre-ADA State Laws Prohibiting Disability Discrimination by Private Employers}

\begin{tabular}{|c|c|c|}
\hline State & Legal Description & $\begin{array}{l}\text { Effect on Results for Post-ADA } \\
\text { Years 90-91, 91-92, and 92-93 }\end{array}$ \\
\hline Pennsylvania & $\begin{array}{l}\text { Pennsylvania's reasonable accommodations } \\
\text { requirement was imposed only by an } \\
\text { intermediate court, rather than by the state's } \\
\text { highest court. }\end{array}$ & $\begin{array}{l}\text { Categorizing Pennsylvania as a "protection without } \\
\text { accommodation" state, rather than an "ADA-like" } \\
\text { state, does not alter the basic pattern of our results. } \\
\text { Our estimates of } \beta_{11} \text { (the effect of imposing a } \\
\text { reasonable accommodations requirement) are } \\
\text { somewhat smaller in magnitude and slightly less } \\
\text { precise. Our estimates of } \beta_{12}-\beta_{11} \text { (the effect of } \\
\text { imposing a traditional antidiscrimination provision) } \\
\text { remain insignificant in all years. }\end{array}$ \\
\hline South Dakota & $\begin{array}{l}\text { Limited accommodation provision, not expressly } \\
\text { requiring reasonable accommodations, was } \\
\text { adopted in } 1986 .\end{array}$ & $\begin{array}{l}\text { Categorizing South Dakota as an "ADA-like" state, } \\
\text { rather than a "protection without accommodation" } \\
\text { state, improves the precision of our estimates of } \beta_{l I} \\
\text { (the effect of imposing a reasonable } \\
\text { accommodations requirement), with little effect on } \\
\text { their magnitudes. Our estimates of } \beta_{l 2}-\beta_{l 1} \text { (the } \\
\text { effect of imposing a traditional antidiscrimination } \\
\text { provision) remain insignificant in all years. }\end{array}$ \\
\hline Texas & $\begin{array}{l}\text { Remedy provisions refer to reasonable } \\
\text { accommodations (Civ. Art. 5221k:6.01(d) and } \\
\text { 7.01(f)). }\end{array}$ & $\begin{array}{l}\text { Categorizing Texas as an "ADA-like" state, rather } \\
\text { than a "protection without accommodation" state, } \\
\text { does not alter the basic pattern of our results. Our } \\
\text { estimates of } \beta_{11} \text { (the effect of imposing a reasonable } \\
\text { accommodations requirement) are somewhat } \\
\text { smaller in magnitude and also somewhat less } \\
\text { precise. Our estimates of } \beta_{12}-\beta_{11} \text { (the effect of } \\
\text { imposing a traditional antidiscrimination provision) } \\
\text { remain insignificant in all years. }\end{array}$ \\
\hline Wisconsin & $\begin{array}{l}\text { The Wisconsin legislature adopted a } \\
\text { reasonable accommodations requirement in } \\
\text { 1981, but in the preceding period some } \\
\text { Wisconsin lower courts judicially imposed a } \\
\text { reasonable accommodations requirement (e.g., } \\
\text { Teggatz v. Labor \& Industry Review Comm'n, } \\
1978 \text { WL } 3436 \text { (Cir. Ct. Wisc.)), while others } \\
\text { did not impose such a requirement (e.g., } \\
\text { Samens v. Labor \& Industry Review Comm'n, } \\
1981 \text { WL } 11474 \text { (Cir. Ct. Wisc.)). }\end{array}$ & $\begin{array}{l}\text { This change cannot affect our results (because the } \\
\text { timing of state law adoption does not enter into our } \\
\text { categorization of states). }\end{array}$ \\
\hline
\end{tabular}


Table A3: Basic Regression Results - Overall State-Group Effects

\begin{tabular}{|c|c|c|c|c|c|c|c|c|}
\hline $\begin{array}{l}\text { Specification with } \\
\text { ADA*DIS*AD }\end{array}$ & $90-91$ & $91-92$ & $92-93$ & 93-94 & $94-95$ & $95-96$ & 96-97 & $97-98$ \\
\hline Coeff. on ADA*DIS*LP & $\begin{array}{r}-0.91 \\
(0.41) \\
{[0.57]}\end{array}$ & $\begin{array}{r}-0.84 \\
(0.55) \\
{[0.57]}\end{array}$ & $\begin{array}{r}-1.03 \\
(0.65) \\
{[0.63]}\end{array}$ & $\begin{array}{r}-1.08 \\
(0.60) \\
{[0.60]}\end{array}$ & $\begin{array}{r}-1.21 \\
(0.46) \\
{[0.53]}\end{array}$ & $\begin{array}{r}-1.34 \\
(0.51) \\
{[0.53]}\end{array}$ & $\begin{array}{r}-1.84 \\
(0.53) \\
{[0.56]}\end{array}$ & $\begin{array}{r}-2.64 \\
(0.51) \\
{[0.56]}\end{array}$ \\
\hline Coeff. on ADA*DIS*NP & $\begin{array}{r}-1.40 \\
(0.58) \\
{[0.77]}\end{array}$ & $\begin{array}{r}-0.29 \\
(0.57) \\
{[0.80]}\end{array}$ & $\begin{array}{r}-0.61 \\
(0.70) \\
{[0.74]}\end{array}$ & $\begin{array}{r}-1.33 \\
(1.08) \\
{[0.79]}\end{array}$ & $\begin{array}{r}-0.34 \\
(1.34) \\
{[1.05]}\end{array}$ & $\begin{array}{r}-1.02 \\
(1.02) \\
{[0.96]}\end{array}$ & $\begin{array}{r}-1.80 \\
(0.61) \\
{[0.62]}\end{array}$ & $\begin{array}{r}-2.42 \\
(0.59) \\
{[0.75]}\end{array}$ \\
\hline Coeff. on ADA*DIS*AD & $\begin{array}{l}1.23 \\
(0.63) \\
{[0.93]}\end{array}$ & $\begin{array}{l}1.67 \\
(0.78) \\
{[0.96]}\end{array}$ & $\begin{array}{c}0.51 \\
(0.51) \\
{[0.98]}\end{array}$ & $\begin{array}{r}-0.99 \\
(0.52) \\
{[0.88]}\end{array}$ & $\begin{array}{r}-1.92 \\
(0.49) \\
{[0.82]}\end{array}$ & $\begin{array}{r}-1.46 \\
(0.61) \\
{[0.92]}\end{array}$ & $\begin{array}{r}-1.23 \\
(0.70) \\
{[0.93]}\end{array}$ & $\begin{array}{r}-2.67 \\
(0.58) \\
{[0.88]}\end{array}$ \\
\hline $\begin{array}{c}\text { Specification with } \\
\text { ADA*DIS*AD and State, } \\
\text { Year, and State*Year } \\
\text { Fixed Effects }\end{array}$ & $90-91$ & $91-92$ & $92-93$ & 93-94 & $94-95$ & $95-96$ & $96-97$ & $97-98$ \\
\hline Coeff. on ADA*DIS*LP & $\begin{array}{r}-0.90 \\
(0.33) \\
{[0.39]}\end{array}$ & $\begin{array}{r}-0.84 \\
(0.44) \\
{[0.46]}\end{array}$ & $\begin{array}{r}-0.99 \\
(0.53) \\
{[0.54]}\end{array}$ & $\begin{array}{r}-1.02 \\
(0.47) \\
{[0.47]}\end{array}$ & $\begin{array}{r}-1.12 \\
(0.32) \\
{[0.41]}\end{array}$ & $\begin{array}{r}-1.27 \\
(0.39) \\
{[0.42]}\end{array}$ & $\begin{array}{r}-1.79 \\
(0.37) \\
{[0.44]}\end{array}$ & $\begin{array}{r}-2.58 \\
(0.39) \\
{[0.40]}\end{array}$ \\
\hline Coeff. on ADA*DIS*NP & $\begin{array}{r}-1.43 \\
(0.29) \\
{[0.57]}\end{array}$ & $\begin{array}{r}-0.31 \\
(0.44) \\
{[0.69]}\end{array}$ & $\begin{array}{r}-0.63 \\
(0.65) \\
{[0.69]}\end{array}$ & $\begin{array}{r}-1.32 \\
(1.07) \\
{[0.80]}\end{array}$ & $\begin{array}{r}-0.30 \\
(1.40) \\
{[1.02]}\end{array}$ & $\begin{array}{r}-0.99 \\
(0.89) \\
{[0.96]}\end{array}$ & $\begin{array}{r}-1.74 \\
(0.46) \\
{[0.54]}\end{array}$ & $\begin{array}{r}-2.41 \\
(0.44) \\
{[0.63]}\end{array}$ \\
\hline Coeff. on ADA*DIS*AD & $\begin{array}{l}1.32 \\
(0.59) \\
{[0.44]}\end{array}$ & $\begin{array}{l}1.72 \\
(0.72) \\
{[0.82]}\end{array}$ & $\begin{array}{l}0.55 \\
(0.43) \\
{[0.80]}\end{array}$ & $\begin{array}{r}-0.96 \\
(0.48) \\
{[0.69]}\end{array}$ & $\begin{array}{r}-1.89 \\
(0.48) \\
{[0.67]}\end{array}$ & $\begin{array}{r}-1.41 \\
(0.58) \\
{[0.77]}\end{array}$ & $\begin{array}{r}-1.19 \\
(0.70) \\
{[0.79]}\end{array}$ & $\begin{array}{r}-2.68 \\
(0.50) \\
{[0.74]}\end{array}$ \\
\hline No. of Obse rvations & 292,562 & 291,149 & 286,796 & 283,860 & 274,988 & 265,866 & 266,478 & 266,838 \\
\hline
\end{tabular}

Notes: Results duplicate the first two panels of Table 5 except that state-group effects are overall effects for each state group rather than effects in the "protection without accommodation" and "no protection" groups relative to "ADA-like" states. ADA*DIS*AD replaces ADA*DIS in all regressions in this table. The dependent variable is weeks worked per year. The pre-ADA period is 1988-1989. The post-ADA period is as stated. Robust standard errors clustered on state-disability interactions are in parentheses below coefficient estimates, and robust standard errors clustered on state-disability-year interactions are in square brackets below coefficient estimates. All regressions are OLS regressions and employ CPS survey weights. Control variables are as stated in Table 5. 
Table A4: Alternative Fixed Effects Specifications

\begin{tabular}{|c|c|c|c|c|c|c|c|c|}
\hline $\begin{array}{c}\text { Specification with State, } \\
\text { State*Year, and } \\
\text { State*Dis abled Fixed Effects }\end{array}$ & $90-91$ & $91-92$ & $92-93$ & 93-94 & 94-95 & 95-96 & $96-97$ & $97-98$ \\
\hline Coeff. on ADA*DIS & $\begin{array}{l}1.07 \\
(0.55) \\
{[0.46]}\end{array}$ & $\begin{array}{l}1.26 \\
(0.66) \\
{[0.51]}\end{array}$ & $\begin{array}{l}-0.06 \\
(0.42) \\
{[0.59]}\end{array}$ & $\begin{array}{l}-1.13 \\
(0.52) \\
{[0.50]}\end{array}$ & $\begin{array}{l}-1.84 \\
(0.51) \\
{[0.51]}\end{array}$ & $\begin{array}{l}-1.32 \\
(0.60) \\
{[0.56]}\end{array}$ & $\begin{array}{l}-1.02 \\
(0.72) \\
{[0.54]}\end{array}$ & $\begin{array}{l}-2.32 \\
(0.48) \\
{[0.50]}\end{array}$ \\
\hline Coeff. on ADA*DIS*LP & $\begin{array}{l}-2.10 \\
(0.63) \\
{[0.53]}\end{array}$ & $\begin{array}{l}-2.53 \\
(0.64) \\
{[0.55]}\end{array}$ & $\begin{array}{l}-1.74 \\
(0.51) \\
{[0.67]}\end{array}$ & $\begin{array}{l}-0.21 \\
(0.62) \\
{[0.60]}\end{array}$ & $\begin{array}{l}0.63 \\
(0.56) \\
{[0.59]}\end{array}$ & $\begin{array}{r}0.05 \\
(0.69) \\
{[0.63]}\end{array}$ & $\begin{array}{l}-0.72 \\
(0.79) \\
{[0.62]}\end{array}$ & $\begin{array}{r}0.00 \\
(0.58) \\
{[0.55]}\end{array}$ \\
\hline Coeff. on ADA $* D I S * N P$ & $\begin{array}{l}-2.48 \\
(0.63) \\
{[0.72]}\end{array}$ & $\begin{array}{l}-1.65 \\
(0.79) \\
{[0.80]}\end{array}$ & $\begin{array}{l}-0.50 \\
(0.82) \\
{[0.89]}\end{array}$ & $\begin{array}{l}0.03 \\
(1.20) \\
{[0.90]}\end{array}$ & $\begin{array}{r}1.86 \\
(1.44) \\
{[0.94]}\end{array}$ & $\begin{array}{l}0.75 \\
(1.08) \\
{[1.01]}\end{array}$ & $\begin{array}{r}0.12 \\
(0.83) \\
{[0.75]}\end{array}$ & $\begin{array}{r}0.83 \\
(0.64) \\
{[0.77]}\end{array}$ \\
\hline $\begin{array}{l}\text { Coeff. on ADA*DIS*NP } \\
\text { Coeff. on ADA*DIS*LP }\end{array}$ & $\begin{array}{l}-0.38 \\
(0.44) \\
{[0.61]}\end{array}$ & $\begin{array}{r}0.89 \\
(0.60) \\
{[0.72]}\end{array}$ & $\begin{array}{l}1.24 \\
(0.88) \\
{[0.85]}\end{array}$ & $\begin{array}{l}0.24 \\
(1.14) \\
{[0.84]}\end{array}$ & $\begin{array}{l}1.23 \\
(1.32) \\
{[0.85]}\end{array}$ & $\begin{array}{r}0.70 \\
(0.88) \\
{[0.89]}\end{array}$ & $\begin{array}{r}0.84 \\
(0.53) \\
{[0.61]}\end{array}$ & $\begin{array}{r}0.83 \\
(0.47) \\
{[0.66]}\end{array}$ \\
\hline $\begin{array}{c}\text { Specification with Year, } \\
\text { Dis abled, and Year*Dis abled } \\
\text { Fixed Effects }\end{array}$ & $90-91$ & $91-92$ & $92-93$ & 93-94 & 94-95 & $95-96$ & $96-97$ & 97-98 \\
\hline Coeff. on ADA*DIS*LP & $\begin{array}{l}-2.13 \\
(0.69) \\
{[1.04]}\end{array}$ & $\begin{array}{l}-2.52 \\
(0.74) \\
{[1.03]}\end{array}$ & $\begin{array}{l}-1.51 \\
(0.70) \\
{[1.07]}\end{array}$ & $\begin{array}{l}-0.08 \\
(0.78) \\
{[1.03]}\end{array}$ & $\begin{array}{r}0.70 \\
(0.69) \\
{[0.97]}\end{array}$ & $\begin{array}{l}0.12 \\
(0.79) \\
{[1.05]}\end{array}$ & $\begin{array}{c}-0.56 \\
(0.89) \\
{[1.06]}\end{array}$ & $\begin{array}{r}0.05 \\
(0.75) \\
{[0.98]}\end{array}$ \\
\hline Coeff. on ADA*DIS*NP & $\begin{array}{l}-2.66 \\
(0.87) \\
{[1.18]}\end{array}$ & $\begin{array}{c}-1.94 \\
(0.94) \\
{[1.23]}\end{array}$ & $\begin{array}{c}-1.14 \\
(0.87) \\
{[1.14]}\end{array}$ & $\begin{array}{c}-0.38 \\
(1.23) \\
{[1.21]}\end{array}$ & $\begin{array}{r}1.55 \\
(1.43) \\
{[1.36]}\end{array}$ & $\begin{array}{r}0.47 \\
(1.19) \\
{[1.33]}\end{array}$ & $\begin{array}{l}-0.62 \\
(0.87) \\
{[1.09]}\end{array}$ & $\begin{array}{c}0.19 \\
(0.69) \\
{[1.02]}\end{array}$ \\
\hline $\begin{array}{l}\text { Coeff. on ADA*DIS*NP - } \\
\text { Coeff. on ADA*DIS*LP }\end{array}$ & $\begin{array}{l}-0.54 \\
(0.71) \\
{[0.94]}\end{array}$ & $\begin{array}{r}0.58 \\
(0.76) \\
{[0.95]}\end{array}$ & $\begin{array}{r}0.37 \\
(0.96) \\
{[0.87]}\end{array}$ & $\begin{array}{l}-0.30 \\
(1.27) \\
{[1.04]}\end{array}$ & $\begin{array}{r}0.85 \\
(1.39) \\
{[1.21]}\end{array}$ & $\begin{array}{r}0.35 \\
(1.11) \\
{[1.11]}\end{array}$ & $\begin{array}{c}-0.05 \\
(0.81) \\
{[0.80]}\end{array}$ & $\begin{array}{c}0.14 \\
(0.71) \\
{[0.76]}\end{array}$ \\
\hline No. of Obs ervations & 292,562 & 291,149 & 286,796 & 283,860 & 274,988 & 265,866 & 266,478 & 266,838 \\
\hline
\end{tabular}

Notes: The dependent variable is weeks worked per year. The pre-ADA period is 1988-1989. The post-ADA period is as stated. Robust standard errors clustered on state-disability interactions are in parentheses below coefficient estimates, and robust standard errors clustered on state-disability-year interactions are in square brackets below coefficient estimates. All regressions are OLS regressions, employ CPS survey weights, and include the fixed effects specified in the table. Control variables are stated in Table 5. In the upper panel of this table, the fixed effects preclude the estimation of the coefficients on ADA, LP, NP, ADA*LP, ADA*NP, DIS*LP, and DIS*NP from the basic specification in equation (1). In the lower panel, the fixed effects preclude the estimation of the coefficients on ADA, DIS, and ADA*DIS from this specification. 
Table A5: Additional Robustness Checks

\begin{tabular}{|c|c|c|c|c|c|c|c|c|}
\hline $\begin{array}{c}\text { (1) Specification Omitting } \\
\text { State-Level Une mployment } \\
\text { Variables }\end{array}$ & 90-91 & 91-92 & $92-93$ & 93-94 & 94-95 & $95-96$ & $96-97$ & $97-98$ \\
\hline Coeff. on ADA*DIS & $\begin{array}{l}1.34 \\
(0.54) \\
{[0.75]}\end{array}$ & $\begin{array}{l}1.72 \\
(0.57) \\
{[0.76]}\end{array}$ & $\begin{array}{l}0.57 \\
(0.31) \\
{[0.76]}\end{array}$ & $\begin{array}{l}-0.98 \\
(0.46) \\
{[0.68]}\end{array}$ & $\begin{array}{l}-1.91 \\
(0.49) \\
{[0.68]}\end{array}$ & $\begin{array}{l}-1.41 \\
(0.59) \\
{[0.77]}\end{array}$ & $\begin{array}{l}-1.14 \\
(0.70) \\
{[0.78]}\end{array}$ & $\begin{array}{l}-2.44 \\
(0.44) \\
{[0.72]}\end{array}$ \\
\hline Coeff. on ADA*DIS*LP & $\begin{array}{l}-2.22 \\
(0.63) \\
{[0.85]}\end{array}$ & $\begin{array}{l}-2.56 \\
(0.64) \\
{[0.85]}\end{array}$ & $\begin{array}{l}-1.53 \\
(0.51) \\
{[0.88]}\end{array}$ & $\begin{array}{l}-0.08 \\
(0.64) \\
{[0.81]}\end{array}$ & $\begin{array}{r}0.73 \\
(0.58) \\
{[0.79]}\end{array}$ & $\begin{array}{r}0.13 \\
(0.70) \\
{[0.87]}\end{array}$ & $\begin{array}{l}-0.63 \\
(0.77) \\
{[0.89]}\end{array}$ & $\begin{array}{l}0.05 \\
(0.54) \\
{[0.81]}\end{array}$ \\
\hline Coeff. on ADA*DIS*NP & $\begin{array}{l}-2.77 \\
(0.61) \\
{[0.95]}\end{array}$ & $\begin{array}{l}-2.03 \\
(0.72) \\
{[1.03]}\end{array}$ & $\begin{array}{l}-1.20 \\
(0.72) \\
{[1.03]}\end{array}$ & $\begin{array}{l}-0.30 \\
(1.16) \\
{[1.05]}\end{array}$ & $\begin{array}{l}1.76 \\
(1.45) \\
{[1.20]}\end{array}$ & $\begin{array}{l}0.55 \\
(1.00) \\
{[1.19]}\end{array}$ & $\begin{array}{l}-0.34 \\
(0.73) \\
{[0.89]}\end{array}$ & $\begin{array}{l}0.65 \\
(0.48) \\
{[0.90]}\end{array}$ \\
\hline $\begin{array}{l}\text { Coeff. on ADA*DIS*NP }- \\
\text { Coeff. on ADA*DIS*LP }\end{array}$ & $\begin{array}{l}-0.55 \\
(0.43) \\
{[0.68]}\end{array}$ & $\begin{array}{l}-0.53 \\
(0.53) \\
{[0.78]}\end{array}$ & $\begin{array}{r}0.34 \\
(0.76) \\
{[0.81]}\end{array}$ & $\begin{array}{l}-0.22 \\
(1.15) \\
{[0.91]}\end{array}$ & $\begin{array}{r}1.02 \\
(1.40) \\
{[1.07]}\end{array}$ & $\begin{array}{l}0.42 \\
(0.90) \\
{[1.00]}\end{array}$ & $\begin{array}{r}0.29 \\
(0.42) \\
{[0.60]}\end{array}$ & $\begin{array}{r}0.60 \\
(0.38) \\
{[0.66]}\end{array}$ \\
\hline No. of Obs e rvations & 292,562 & 291,149 & 286,796 & 283,860 & 274,988 & 265,866 & 266,478 & 266,838 \\
\hline $\begin{array}{l}\text { (2) Sample Includes Only } \\
\text { Observations from } \\
\text { Southern States }\end{array}$ & $90-91$ & $91-92$ & $92-93$ & 93-94 & 94-95 & $95-96$ & $96-97$ & 97-98 \\
\hline Coeff. on ADA*DIS & $\begin{array}{r}0.32 \\
(1.02) \\
{[1.49]}\end{array}$ & $\begin{array}{r}0.93 \\
(0.69) \\
{[1.06]}\end{array}$ & $\begin{array}{l}0.06 \\
(0.57) \\
{[0.29]}\end{array}$ & $\begin{array}{l}-0.81 \\
(0.56) \\
{[0.23]}\end{array}$ & $\begin{array}{l}-1.56 \\
(0.49) \\
{[0.64]}\end{array}$ & $\begin{array}{l}-0.74 \\
(0.83) \\
{[0.28]}\end{array}$ & $\begin{array}{l}-1.05 \\
(0.98) \\
{[1.10]}\end{array}$ & $\begin{array}{l}-4.08 \\
(1.05) \\
{[1.36]}\end{array}$ \\
\hline Coeff. on ADA*DIS*LP & $\begin{array}{l}-1.33 \\
(1.26) \\
{[1.59]}\end{array}$ & $\begin{array}{l}-1.75 \\
(1.06) \\
{[1.18]}\end{array}$ & $\begin{array}{l}-1.78 \\
(1.17) \\
{[0.93]}\end{array}$ & $\begin{array}{l}-0.85 \\
(1.07) \\
{[1.29]}\end{array}$ & $\begin{array}{r}0.59 \\
(0.99) \\
{[0.73]}\end{array}$ & $\begin{array}{r}0.04 \\
(1.42) \\
{[0.85]}\end{array}$ & $\begin{array}{r}0.86 \\
(1.52) \\
{[1.35]}\end{array}$ & $\begin{array}{r}3.50 \\
(1.46) \\
{[1.49]}\end{array}$ \\
\hline Coeff. on ADA*DIS*NP & $\begin{array}{r}-1.68 \\
(1.18) \\
{[1.53)}\end{array}$ & $\begin{array}{r}-1.21 \\
(0.99) \\
{[1.17]}\end{array}$ & $\begin{array}{c}-0.69 \\
(0.90) \\
{[0.76]}\end{array}$ & $\begin{array}{l}-0.43 \\
(0.97) \\
{[1.07]}\end{array}$ & $\begin{array}{r}1.69 \\
(1.03) \\
{[1.43]}\end{array}$ & $\begin{array}{l}-0.05 \\
(1.28) \\
{[0.83]}\end{array}$ & $\begin{array}{l}-0.79 \\
(1.01) \\
{[1.05]}\end{array}$ & $\begin{array}{r}1.70 \\
(1.15) \\
{[1.33]}\end{array}$ \\
\hline $\begin{array}{l}\text { Coeff. on ADA*DIS*NP }- \\
\text { Coeff. on ADA*DIS*LP }\end{array}$ & $\begin{array}{c}-0.35 \\
(0.94) \\
{[0.58]}\end{array}$ & $\begin{array}{r}0.54 \\
(1.05) \\
{[0.65]}\end{array}$ & $\begin{array}{l}1.09 \\
(1.22) \\
{[1.12]}\end{array}$ & $\begin{array}{r}0.42 \\
(1.21) \\
{[1.64]}\end{array}$ & $\begin{array}{r}1.10 \\
(1.30) \\
{[1.34]}\end{array}$ & $\begin{array}{l}-0.10 \\
(1.47) \\
{[1.13]}\end{array}$ & $\begin{array}{c}-1.64 \\
(1.29) \\
{[0.84]}\end{array}$ & $\begin{array}{c}-1.81 \\
(1.21) \\
{[0.72]}\end{array}$ \\
\hline No. of Obs e rvations & 41,793 & 41,786 & 41,157 & 40,813 & 39,169 & 37,612 & 37,832 & 37,593 \\
\hline
\end{tabular}

Notes: The dependent variable is weeks worked per year. The pre-ADA period is $1988-1989$. The post-ADA period is as stated. Robust standard errors clustered on state-disability interactions are in parentheses below coefficient estimates, and robust standard errors clustered on state-disability-year interactions are in square brackets below coefficient estimates. All regressions are OLS regressions, employ CPS survey weights, and include state, year, and state*year fixed effects. Control variables are as stated in Table 5 minus state unemployment rate and the interaction of disability and state unemployment rate in the upper panel. The southern states used in the lower panel are as stated in the text. 